\title{
The Influence of Economic Policy Uncertainty on Corporate Trade Credit and Firm Value* $^{*}$
}

\author{
Surendranath R. Jory \\ Department of Banking and Finance \\ University of Southampton, UK \\ s.r.jory@soton.ac.uk \\ Hinh D. Khieu \\ Department of Accounting, Finance, and Management Information Systems \\ Prairie View A\&M University, USA \\ hikhieu@pvamu.edu \\ Thanh N. Ngo \\ Department of Finance \\ Eastern Carolina University, USA \\ ngot@ecu.edu \\ Hieu V. Phan \\ Department of Finance \\ University of Massachusetts Lowell, USA \\ Hieu_Phan@uml.edu
}

April 2019

Journal of Corporate Finance, Forthcoming

\footnotetext{
* We are grateful to the editor, Douglas Cumming, and two anonymous referees for their comments and suggestions. We thank Alice Bonaime and participants at the 2019 Southern Finance Association Annual Meeting and 2019 Financial Management Association Annual Meeting for helpful discussions.
} 


\title{
The Influence of Economic Policy Uncertainty on Corporate Trade Credit and Firm Value
}

\begin{abstract}
This research investigates the relationship between government economic policy uncertainty (EPU) and trade credit and its value implication for U.S. public firms. We find that firms curtail their receivables periods and face shorter payables periods from suppliers during high EPU. The impact of trade credit policy changes on firm value is nonlinear. Tightening trade credit during periods of high EPU increases shareholder value only to a certain point, beyond which it is value-destroying since overly reducing trade credit can lead to losing customers to competitors.
\end{abstract}

JEL Classifications: G30; G32, G33

Keywords: Trade Credit; Economic Policy Uncertainty; Firm Value 


\section{The Influence of Economic Policy Uncertainty on Corporate Trade Credit and Firm Value}

\section{Introduction}

Trade credit is an important source of short-term external finance for U.S. firms of all sizes (Petersen and Rajan, 1997; Ng et al., 1999; Demirguc-Kunt and Maksimovic, 2001; Aktas et al., 2012). According to the U.S. Flow of Funds Account, trade payables for nonfinancial corporate businesses grew from $\$ 1,790$ billion in 1985 to $\$ 9,558$ billion in 2017, a 434\% increase over the thirty-two year span. Similarly, trade receivables for the same category increased by $325 \%$, from $\$ 2,947$ billion to $\$ 12,509$ billion over the same period. The expansion of trade credit is particularly surprising in light of trade credits' high implied interest rates, typically $43.9 \%$ for a conventional $2 / 30$ credit term.

Academic researchers have provided both theoretical models and empirical evidence that suggests firm-level information asymmetry, financial, operational, and strategic motivations for trade credit use from both the supply and demand sides of non-financial firms. Specifically, supplier firms can use trade credit to reduce information asymmetry about the buyer firms' ability to pay (Cheng and Pike, 2003) and to signal the quality of its investment projects to external investors (Aktas et al., 2012) or product quality to buyers (Lee and Stowe, 1993; Long et al., 1993; Deloof and Jegers, 1996). From the financial perspective, firms with limited access to external debt financing and those with fast growth tend to rely heavily on trade credit (Love and Zaidi, 2010; Boissay and Gropp, 2007; Cunat, 2007; Bougheas et al., 2009, Ferrando and Mulier, 2013). Strategically, providing trade credit enhances the seller's competitive position in the market (Deloof and Jegers, 1996; Ng et al., 1999) and price-discriminates between cash and credit customers (Brennan et al., 1988). 
Given that trade credit closely links buyers and sellers in a supply chain, a shock that triggers changes in corporate trade credit policy could have a wide-ranging effect throughout the supply chain. Prior studies document that EPU adversely affects corporate financing and investments, but surprisingly little is known about its effect on trade credit policy. For example, EPU exacerbates a firm's financial constraints by reducing its asset returns while increasing its cost of external financing (Pastor and Veronesi, 2013; Gilchrist et al., 2014; Brogaard and Detzel, 2015 and Phan et al., 2018). Phan et al. argue that EPU makes firms' future cash flows more volatile, inducing firms to hoard cash to buffer against financial shocks and maintain smooth operations. Gulen and Ion (2016), Bonaime et al. (2017), and Nguyen and Phan (2017) report that firms delay investments and reduce mergers and acquisitions amid high EPU.

EPU is likely to affect trade credit for at least two reasons. First, it can dissuade firms from overproducing and overstocking as the risk of purchase returns and order cancellations heighten, which is consistent with Gulen and Ion (2016)'s finding that capital investment is negatively related to the aggregate level of policy and regulatory uncertainty. A decrease in the supply of, and demand for, merchandise and the need to increase corporate cash reserves during periods of high EPU can undermine firms' bargaining power with their suppliers and weaken their ability to extend trade credit to clients. Second, suppliers of trade credit may use bank loans to fund their outstanding credit. To the extent that EPU increases borrowing costs (Xu, 2020), shortens debt maturity (Tran and Phan, 2020), and creates financial shortages for even financial institutions (Matousek et al., 2020), suppliers will have to decide whether to pass the costs through trade finance (Ahn, Amiti and Weistein, 2011) or to curtail credit extension. EPU could cost firms more than the usual worries of bad debt expenses or forgone interest income. 
In this study, we broaden the line of inquiry discussed above by examining two unexplored questions. First, do firms adjust their trade credit policy in response to EPU? Second, what is the effect of the adjustment of trade credit policy, if any, in periods of heightened EPU on shareholder value? Since we are interested in determining whether EPU impact reverberates across the supply chains, we perform analysis of firm-level trade receivables, payables, and their relative changes.

We study a sample of 288,814 firm-quarter observations, covering 11,196 unique nonfinancial U.S. public firms from 1985 to 2016. Baker et al. (2016) develop an index of EPU for the U.S. based on the count of uncertainty-related keywords in newspaper articles, uncertainty about future changes in the tax code, and dispersions in economic forecasts. ${ }^{1}$ These authors argue that high EPU makes managers risk-averse, leading to conservative corporate policies. Several recent empirical studies use the EPU index to examine the relations between government economic policy uncertainty and corporate behavior (e.g., Gulen and Ion, 2016; Nguyen and Phan, 2017; Bonaime, Gulen, and Ion, 2017). Similar to these studies, we use Baker et al. (2016)'s EPU index to examine the effects of government economic policy uncertainty on trade credit.

To preview our results, we find evidence that supplier firms curtail their receivables days during periods of high EPU while customer firms face shorter payables days from their suppliers during these uncertain times. Further analysis indicates that EPU is positively related to firms' net credit, which is measured as the difference between trade receivables and payables. Our finding of the net credit effect appears to be consistent with Choi and Kim (2005), who report

\footnotetext{
${ }^{1}$ There are a variety of methods to measure policy uncertainty. See Gulen and Ion (2016) for the merits of Baker et al. (2016) EPU Index over the other methods.
} 
that publicly listed firms tend to be net credit suppliers but in a different setting, that is, macrofinancial shocks.

Our results are robust to numerous additional checks. First, Giannetti et al. (2011) document that suppliers of differentiated products and services tend to have larger accounts receivable than suppliers of standardized goods. The intuition is that the buyer firms of unique inputs are less likely to default because it is harder for them to replace suppliers, making the supplier firms more willing to sell on credit. We find that both firms that trade differentiated goods and service and those that trade in standardized and homogeneous products tighten their trade credit during high EPU periods, although the latter do so at a smaller scale. Our finding suggests that the EPU impact on trade credit is not sensitive to the types of products a firm is selling or using as inputs.

Second, changes in trade credit policy during high EPU periods could depend on firms’ financial conditions. Garcia-Appedini and Montoriol-Garriga (2013) find that financially unconstrained firms are more able to extend trade credit to help the constrained ones. Zhang et al. (2015) document that firm leverage ratios are negatively related to EPU due to a "supply effect” since the external financing environment becomes more restrictive during times of high EPU. We find that EPU is associated with tightened trade credit policy for both financially constrained and unconstrained firms.

Third, Fabbri and Klapper (2008) and Dass et al. (2015) report that firms with larger market power are able to obtain extended credit periods from their suppliers while granting shorter credit periods to their clients. Similarly, large buyers are in a position of strength to negotiate favorable credit terms with their suppliers (Love and Zaidi, 2010). Based on the financing view, though, Dass et al. (2015) argue that more profitable and powerful firms would 
extend longer (as opposed to shorter) credit periods to their trading partners. Gonçalves et al. (2018) find that the larger the firm's market power, the shorter its payment time to suppliers following a crisis. We investigate whether the effects of EPU on trade credit policy are restricted to only firms with high market power and find that EPU is negatively related to trade credit of firms across the market power spectrum.

Fourth, Dass et al. (2015) examine the impact of credit rating upgrade and downgrade on trade credit provisions separately for non-relationship-specific investments (RSI) and RSIintensive firms. They document that RSI-intensive firms behave differently from non-RSIintensive firms as the former provide more trade credit following the changes in credit ratings. We control for RSI in our analysis but our results remain qualitatively unchanged.

Fifth, following Gulen and Ion (2016), Nguyen and Phan (2017), and Drobetz et al. (2018), we check whether firms' dependence on government spending influences their trade credit decisions since the EPU index construct may be more applicable to firms that depend on government spending. Splitting the sample firms into government-dependent and non-dependent subgroups for analysis, we find that EPU negatively affects trade credit policies of both subgroups, even though the impact appears to be stronger for the government-dependent one.

Finally, although our regression models control for firm and year fixed effects, we conduct additional tests to address potential concerns about omitted variable bias and error-in measurement bias. In particular, to rule out a possibility that the EPU index merely picks up the effects of other economic uncertainty, we control for several macroeconomic variables and indices such as the average monthly Organization for Economic Co-operation and Development (OECD) composite confidence indicator for the U.S., the average monthly University of Michigan's consumer sentiment index of the U.S., the average monthly expected inflation, and 
the monetary policy uncertainty index developed by Husted, Rogers and Sun (2016). Our findings continue to hold.

The next natural question is whether trade credit policy changes due to EPU affect firm value. Similar to Dittmar and Mahrt-Smith (2007), we use the market-to-book model to gauge the marginal effect of trade credit changes on firm value. We find that tightening the trade credit for clients during the high EPU periods is associated with higher firm value. However, consistent with Martinez-Sola et al. (2013) and Hill et al. (2015), we document that tightening trade credit amid high EPU enhances firm value only to a point, beyond which it is value-decreasing.

We further investigate why being overly cautious with trade credit provision during high EPU periods could destroy the supplier's shareholder wealth. Our analysis indicates that the value destruction is greater for firms operating in highly competitive industries. This evidence suggests that tightening credit policy too much for too long as a buffer against EPU might drive customers toward a competitor, who might pursue a more aggressive strategy with respect to customer acquisition and market share.

Our research contributes to the literature in three important ways. First, our study adds to the growing literature that examines the effects of EPU on corporate policies (e.g., Bloom et al., 2007; Gulen and Ion, 2016; Baker et al., 2016; Nguyen and Phan, 2017; Bonaime et al., 2017). In particular, our research highlights the adverse effect of policy uncertainty on firm trade credit, one of the most crucial working capital sources. Second, we document the value effect of EPUrelated trade credit policy adjustments along the supply chain. Our evidence based on a sample of non-financial U.S. public firms indicates an inverse U-shaped relation between EPU-induced trade credit policy and firm value and, importantly, we show product market competition as a driver of the concave relation. Finally, given the recent political turmoil (e.g., increasing trade 
tensions between major trading partners and rising trade protectionism), our findings inform regulators in their policy making process and corporate decision-makers in formulating working capital strategies.

The remainder of the paper proceeds as follows. We review the related literature and develop our testable hypotheses in Section 2. In Section 3, we present the sample data, variables, and methods. We provide empirical results and discussions in Section 4. Section 5 concludes the paper.

\section{Literature Review and Hypothesis Development}

\subsection{Economic Policy Uncertainty (EPU) and Trade Credit}

The extant studies group the trade credit motives of non-financial firms into four categories: information asymmetry reduction, operation, strategy, and financing. Specifically, by extending trade credit to the buyers, supplier firms can mitigate information asymmetry about product quality, which is not known to the buyers at the time of placing the order. Supplier firms can also use trade credit to identify clients with cash flow problems. Buyer firms who delay payment, thereby passing the usual discount incentive, will require stricter monitoring than those that promptly pay the invoices.

Ferris (1981) argues that separating the exchange of goods from the exchange of money can reduce transaction costs. Cheng and Pike (2003) suggest that larger firms can avoid operational inefficiencies by allowing their clients to lump payments for multiple merchandise deliveries into a single payment transaction since this selling-delivery-collection process reduces costly monitoring. Thus, trade credit can serve as an important operational instrument. 
Strategically, credit extension stimulates customer demand, fosters long-term customer relationships and, thus, ensures stable future cash flows (Nadiri, 1969). Trade credit enhances the seller's competitive position in the market (Deloof and Jegers, 1996; Ng et al., 1999). Banks are more likely to loan funds to firms that are able to obtain longer repayment periods from their suppliers (Brennan et al., 1988; Biais and Gollier, 1997). Finally, trade credit can redistribute capital from financially unconstrained firms to constrained ones (Garcia-Appedini and Montoriol-Garriga, 2013). Schwartz (1974) reports that upstream firms with low financing costs even borrow funds to extend trade credit to downstream firms with high borrowing costs.

Collectively, previous studies assume that a seller firm is always willing to provide trade credit to its customers as long as the marginal benefits exceed the marginal costs. In this research, we are interested in investigating whether and how supplier firms alter their trade credit policy when they face uncertainty from the external business environment that potentially erodes their liquidity positions while increasing the marginal costs of trade credit. One such situation is the uncertainty related to government economic policies.

The effect of uncertainty on corporate trade credit is unclear ex ante. During periods of high uncertainty, such as economic recessions, demand for products may shrink or fluctuate. Emery (1984) argues that firms can respond to demand fluctuations by modifying operations, changing prices or productions, or offering trade credit. Emery explains that by extending trade credit, firms can effectively shift deviations in demand for products to those of the account receivable balance. This argument suggests that the supplier firm should be increasing the trade credit length or volume or both in periods of uncertainty because cutting down on trade credit could exacerbate the downturn and drive customers away or even out of business. Indeed, Choi and Kim (2005) document that both accounts payable and receivable increase during macro- 
financial shock periods. Ferrando and Mulier (2013) report that non-financial firms' trade credit served as a buffer during the recent 2007-2009 financial crisis in the Euro area. Aktas et al. (2012) show that firms prefer using trade credit (extended to them by their sellers) even though the cost of payables is higher than that of other financing channels such as bank credit.

EPU, which refers to the risk arising from uncertain changes in fiscal, regulatory, and monetary policies at the macroeconomic level, appears to be more consequential than temporary economic downturns. Gulen and Ion (2016) find a negative relation between corporate investment and economic policy uncertainty. Nguyen and Phan (2017) and Bonaime et al. (2017) document that EPU leads to a decrease in aggregate merger and acquisition (M\&A) volume and an increase in the time it takes to complete M\&A deals. EPU can also exacerbate a firm's financial constraint by reducing its asset returns and increasing its cost of debt (e.g., Greenwald and Stiglitz, 1990; Panousi and Papanikolaou, 2012; Pastor and Veronesi, 2013; Gilchrist et al., 2014; Brogaard and Detzel, 2015). Phan et al. (2018) document that firms increase cash reserves during periods of high policy uncertainty. Baker et al. (2016) point out that EPU aggravates the consequences of the economic recession and inhibits economic recovery. With both buyers and sellers facing liquidity risk during periods of high EPU, buyers who need trade credit might not be able to obtain it since sellers might demand a quicker payoff to increase their cash buffer or they might charge higher costs for longer payable periods since they need to finance such delayed payment themselves. More receivables spurred by generous credit terms could entail more bad debts and even subsequent greater additional sale revenue to offset the loss amid high EPU. To put this argument into perspective, for example, if a supplier has a 10\% profit margin and one of its customers defaults on a $\$ 100,000$ invoice, it has to generate one million dollars in 
new sales to recoup from the loss, which would be a daunting task under EPU-induced contracting market conditions.

In a perfect market, buyers can obtain capital from external markets and do not need trade credit. Market imperfections, however, push the selling firm to require a higher return for their liquidity reserves when extending trade credit, thus serving as a financial intermediary (Emery, 1984). Schwartz (1974) and Ferris (1981) argue that when credit length increases, trade credit becomes a financing rather than a trade tool. Providers of trade credit as a financing instrument then become more concerned about credit risk, which increases during high EPU periods. Moreover, Tran and Phan (2020) find that EPU is negatively related to debt maturity and positively related to the cost of debt and restrictive loan covenants. Wang et al. (2018) and Kaviani et al. (2017) document that EPU is positively related to credit default swap (CDS) spreads. Wang et al. further report that EPU makes credit protection not only costlier but also more difficult to purchase for investors. Even banks face capital shortages during the high EPU periods (Matousek et al., 2020). These findings suggest that financing incentives may dominate other operational motives as seller firms set the trade credit terms amid EPU.

In summary, during times of policy uncertainty, seller firms become more risk averse and cut down on capital investments and acquisitions, banks are more hesitant to lend, insurance companies are less likely to insure receivables (see Wilson, 2008) or charge higher insurance premiums, costs of capital increase, debt maturity shortens, firms hoard cash, and borrowers' credit risk increases. Against this backdrop, we predict that during the periods of high EPU supplier firms become more prudent with their liquidity, leading them to curtail the trade credit offered to their clients. Following these discussions, we hypothesize that EPU is negatively related to firms’ receivables and payables. 


\subsection{Impact of trade credit policy changes on firm value}

The ultimate market judgment of the wisdom of managerial decisions to alter trade credit policy amid EPU must rest with whether firm risk and cash flows increase. As far as risk is concerned, Baker et al. (2013) document a positive correlation between the S\&P 500 index returns volatility and EPU. Pastor and Veronesi (2012, 2013) and Brogaard and Detzel (2015) find that EPU commands a risk premium in U.S. stock returns because of non-diversifiable political risk. Xu (2020) finds that firms’ cost of capital increases under EPU. Tran and Phan (2020) report that EPU is positively related to the cost of debt and stringent loan covenants and negatively related to debt maturity. Bordo, Duca, and Koch (2016) show that EPU slows down bank-level credit growth, while Matousek et al. (2020) document that aggregate bank capital faces shortages during high EPU periods. Taken together, these findings suggest that extending trade credit during high EPU periods exposes supplier firms to higher financial risk.

Firm cash flows may increase or decrease due to the tightening or loosening of trade credit policy, and the net effect is not immediately obvious. Trade credit policy changes can affect cash flows through discount incentives, financing costs, bad debt expenses, and credit management costs (Kim and Atkins, 1978; Sartoris and Hill, 1981; and Mian and Smith, 1992). First, shortened credit cycle comes with discount granted to incentivize buyers to pay more quickly, which negatively affects cash receipts and, in turn, the seller's profitability and liquidity. Second, quicker cash inflows can save supplier firms from incurring interest expenses on short term financing to fund outstanding accounts, but they may need to tap lines of credit to meet their own account payable obligations, which could become more challenging since banks face capital shortages themselves (Masoutek et al., 2020). Third, allowances for doubtful accounts

and default risk will be reduced when buyers have to pay early, thus helping the bottom line 
(Cheng and Pike, 2003). In times of high EPU, as firms reduce investments and cancel orders, merchandise returns, or even defaults are highly likely. Fourth, a credit tightening and reduction in accounts receivable and bad debt allowances reduce the costs associated with managing credit activities on a daily basis. The net effect could be an increase in cash flow fluctuations since a timing mismatch between receivables and payables may negate the offsetting effect of cash inflows and outflows.

Notwithstanding the above, one may argue that EPU-induced trade credit cut may not hurt supplier firms' cash flows in the short run due to the supplier-customer relationship and product specificity. For example, customers happy with generous trade credit are more loyal as the credit extension sends signals about the product quality, thus helping to maintain stable cash flows for supplier firms. Customers may not find alternative sellers easily, especially when firms in the same industry are facing the same uncertainty. Also, customers that depend on unique sellers due to the specificity of the merchandise or inputs ordered may have high switching costs and thus need to remain loyal to their existing suppliers. Since the net effects of EPU on cash flows discussed above are ambiguous, we are agnostic about our expectations of the marginal effect of the EPU-induced tightening of trade credit policy on firm value and leave the answer to empirical work.

However, the relationship between trade credit and firm value, if any, could be nonlinear. Examining a sample of listed Spanish firms from 2001 to 2007, Martinez-Sola et al. (2013) document that financial, operational, and commercial benefits increase with trade credit at a lower level of receivables and beyond that, the opportunity and financing costs dominate. Hill et al. (2015) document that extending trade credit has a diminishing return on the value of receivables. They further argue that tighter trade credit policies have more value impact for firms 
with larger and higher market shares and higher payout ratios. Therefore, we are interested in exploring whether there exists a similar inverted-U relationship between EPU-induced changes in trade credit and firm value.

\section{Sample Data, Variable Descriptions, and Methods}

We start with 1,472,930 firm-quarter observations in Compustat Fundamentals Quarterly database from 1980-2017. We remove firm-quarter observations without trade receivables (variable RECTRQ in Compustat); 434,173 firm-quarter observations remain as a result. We then remove firm-quarter observations without trade payables (variable $A P Q$ in Compustat) and the sample is further reduced to 431,145. Since quarterly data for the required variables before 2003 are inconsistent, our sample starts from 2003 and has 429,033 firm-quarter observations. We further remove observations with negative market capitalization, negative asset, negative sales and the sample size decreases to 391,693 firm-quarter observations. Finally, we remove firms from the financial industries (with SIC codes from 6000 to 6999). The final sample includes 288,814 firm-quarter observations, covering 11,196 unique public firms.

We report the sample distribution by year and by Fama-French 48-sector classifications in Table 1. The number of firm-year observations increases monotonically from 2004 to 2007 and then starts to decrease. The industry that is most represented in the sample is Business Services, while the Cigarette and related products industry are the least represented. ${ }^{2}$

\section{[INSERT TABLE 1 ABOUT HERE]}

\subsection{Trade credit variables}

\footnotetext{
2 The results are robust even after we drop this industry since its receivables and payables data are scarce.
} 
Following prior studies (e.g., Ferrando and Mulier, 2013; Dass et al., 2015; Fabbri and Klapper, 2016; Box et al., 2018), we compute the following three measures of firm trade credit policy:

REC_DAYS $=($ Trade receivable/Sales $) \times$ Number of actual days in the quarter

PAY_DAYS $=($ Trade payables/Cost of goods sold $) \times$ Number of actual days in the quarter

$N E T \_D A Y S=R E C \_D A Y S-P A Y \_D A Y S$

RECDAYS and PAYDAYS represent the average number of days to receive payment from sales and to pay suppliers, respectively. NET_DAYS is the difference between RECDAYS and PAYDAYS, which indicates whether the firm is a net credit supplier or receiver. Ferrando and Mulier (2013) argue that firms use both accounts receivable and payable to manage performance and growth. These authors note that a firm's ability to extend receivable days is dependent on its payable days, i.e., a firm that receives trade credit from its suppliers is more likely to extend trade credit to its customers. Consequently, both variables together explain corporate trade credit policy.

\subsection{Economic policy uncertainty (EPU)}

Baker et al. (2016) construct the monthly policy uncertainty index (BBD (2016) EPU Index) as the weighted average of the following three components:

(i) a count of the news articles that contain uncertainty-related key terms (i.e., the newsbased component);

(ii) uncertainty about future changes in the federal tax code as measured by the dollar impact of tax provisions set to expire soon (i.e., the tax component); and 
(iii) dispersion in economic forecasts for government spending and the consumer price index (CPI) (i.e., the forecaster disagreement component).

Weighted average policy uncertainty $=1 / 6^{*}$ news-based component $+1 / 3^{*}$ tax component $+1 / 2$ forecaster disagreement component

The news-based uncertainty component captures the intensity of concerns about policy uncertainty based on a collection of news articles from ten of the most widely circulated newspapers. ${ }^{3}$ News articles that contain key terms in all three categories related to uncertainty, the economy, and policy are included. ${ }^{4}$ Baker et al. (2016) find that this component is positively correlated with the stock market crash (Black Monday 1987), the Gulf War, the 9/11 terrorist attack, the Lehman Brothers bankruptcy, the 2011 debt-ceiling dispute, among others. The second component of the EPU index captures the level of uncertainty related to future changes to the tax code by the discounted value of the revenue effects of all tax provisions set to expire over the next ten years. The federal tax code provision expiration data are obtained from the Congressional Budget Office. The third component measures the inflation and government purchase dispersion calculated as the average of the interquartile ranges of CPI and federal, state, and local government spending forecasts. The fiscal and monetary policies data are obtained from the Federal Reserve Bank of Philadelphia’s Survey of Professional Forecasters.

Since trade credit is measured at a quarterly frequency while economic policy uncertainty (EPU) is measured at a monthly frequency, we calculate two alternative measures of EPU as follows:

\footnotetext{
3 The newspapers are USA Today, the Miami Herald, the Chicago Tribune, the Washington Post, the Los Angeles Times, the Boston Globe, the San Francisco Chronicle, the Dallas Morning News, the New York Times, and the Wall Street Journal.

4 They key terms are "uncertainty” or “uncertain”; “economic” or “economy”; and “Congress,” “legislation,” "White House,” "regulation,” "Federal Reserve,” or “deficit”.
} 
(i) EPU_LAST is the natural logarithm of the EPU value in the last month of each quarter. $^{5}$

(ii) EPU_MEAN is the natural logarithm of the average monthly EPU values in each quarter. $^{6}$

Gulen and Ion (2016) find that most of the explanatory power of Baker et al. (2016) EPU Index is attributable to the news-based component; therefore, we additionally examine the separate effect of the news-based uncertainty component of the index on trade credit. We calculate the natural logarithm of the average monthly news-based EPU values in a quarter (NEWS_EPU_MEAN) and the natural logarithm of the last monthly news-based EPU values in a quarter (NEWS_EPU_LAST) and use these two measures in the robustness analysis.

We report the summary statistics of the variables in Table 2 . The average values of the natural logarithm of economic policy uncertainty measures EPU_LAST and EPU_MEAN are 4.707 and 4.695, respectively. Based on the mean values, the sample payable days exceed the receivable days (81.452 versus 51.975); however, the reverse is true using the median values (46.182 versus 49.642), which is consistent with the literature (see Goncalves et al. (2018)). The average firm is profitable based on the mean GROSSMARGIN value (0.245).

\section{[INSERT TABLE 2 ABOUT HERE]}

\subsection{Empirical methods}

\subsubsection{EPU and trade credit policy}

\footnotetext{
${ }^{5}$ In an untabulated analysis, we include longer lags of EPU in our baseline regressions and find that EPU affects trade credit up to two quarters.

${ }^{6}$ Our analysis results are qualitatively similar with either EPU measure.
} 
To examine the impact of EPU on firm trade credit policy while controlling for other firm characteristics, we estimate the following regression model as suggested by Goncalves et al. (2018):

$$
\begin{aligned}
& \text { TRADE CREDIT } T_{i, t}=\alpha_{i}+\beta_{1 i} \text { EPU }_{t-1}+\beta_{2 i} \text { GROSSMARGIN }_{i, t-1}+\beta_{3 i} \text { SALE } /
\end{aligned}
$$

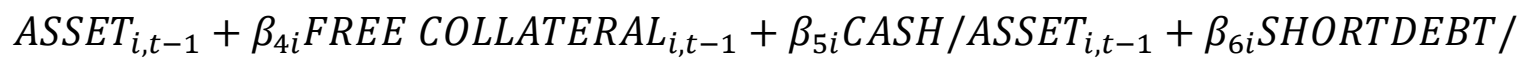

$$
\begin{aligned}
& \operatorname{ASSET}_{i, t-1}+\beta_{7 i} R S I_{i, t-1}+\mu_{i}+\partial_{i}+\varepsilon_{i, t}
\end{aligned}
$$

In the above equation, the dependent variable TRADE CREDIT $T_{i, t}$ is either REC_DAYS, or PAY_DAYS, or NET_DAYS. The test variable is $E P U_{t-1}$, which comes in two alternative measures including EPU_LAST and EPU_MEAN as described in Section 3.2. Consistent with our hypothesis, we expect $\beta_{1}$ to be negative and statistically significant. Turning to the set of control variables, GROSSMARGIN $N_{i, t-1}$ is the difference between revenues and cost of goods sold scaled by revenues. Gaspar and Massa (2006) and Dass et al. (2015) control for this variable and refer to it as the Lerner Index/ the price-cost margin. $(S A L E / A S S E T)_{i, t-1}$ is asset turnover. FREE COLLATERAL $L_{i, t-1}$ is calculated as the difference between net fixed asset and long-term debt scaled by total assets. (CASH/ASSET $)_{i, t-1}$, is the cash-to-asset ratio, and (SHORTDEBT / ASSET $_{i, t-1}$ is the short-term debt-to-asset ratio. We control for research and development expenditures, which proxy for relationship-specific investment $\left(R S I_{i, t-1}\right)$ (Dass et al., 2015). ${ }^{7}$ Finally, to account for time-invariant unobserved firm characteristics that may be correlated with both EPU and trade credit and time-varying unobserved effects, we control for firm fixed effects $\left(\mu_{i}\right)$ and year fixed effects $\left(\partial_{i}\right)$, respectively.

\footnotetext{
${ }^{7}$ SALE/ASSET - Firms may use an aggressive trade credit to stimulate sales (Emery, 1984). SHORTDEBT/ASSET It is a proxy for short-term financial distress. Following Molina and Preve (2009), we hypothesize that firms reduce trade credit when they are financially distressed.
} 


\subsubsection{Impact on Firm Value}

To examine the value effect of trade credit policy changes driven by EPU, we follow Dittmar and Mahrt-Smith (2007) and use the market-to-book model but augmented with EPU, trade credit, and their interaction. The model has the following form:

$$
\begin{aligned}
& M B_{i, t+1}=\alpha_{i}+\beta_{1} E_{P} U_{t}+\beta_{2} T_{R A D E} \operatorname{CREDIT}_{i, t+1}+\beta_{3} \text { TRADE } \text { CREDIT }^{2}{ }_{i, t+1}+
\end{aligned}
$$

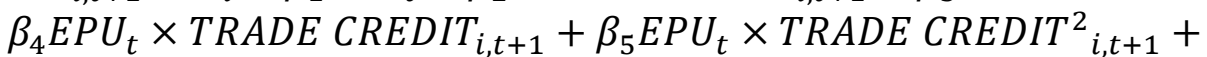

$$
\begin{aligned}
& \beta_{6} \text { EARNINGS }_{i, t+1}+\beta_{7} \text { EARNINGSLAG }_{i, t+1}+\beta_{8} \text { EARNINGSFLAG }_{i, t+1}+ \\
& \beta_{9} \text { ASSETLAG } 2_{i, t+1}+\beta_{10} \text { ASSETFLAG } 2_{i, t+1}+\beta_{11} R D_{i, t+1}+\beta_{12} \text { RDLAG }_{i, t+1}+ \\
& \beta_{13} \text { RDFLAG2 } 2_{i, t+1}+\beta_{14} \text { INTEREST }_{i, t+1}+\beta_{15} \text { INTERESTLAG }_{i, t+1}+ \\
& \beta_{16} \text { INTERESTFLAG } 2_{i, t+1}+\beta_{17} \text { DIVIDEND } D_{i, t+1}+\beta_{18} \text { DIVIDENDLAG } 2_{i, t+1}+ \\
& \beta_{19} \text { DIVIDENDFLAG } 2_{i, t+1}+\beta_{20} \text { MBFLAG }_{i, t+1}+\beta_{21} \text { US_SENTIMENT }_{i, t-1}+ \\
& \beta_{22} U S_{-} C O N F I D E N C E_{i, t-1}+\beta_{23} U S_{-} E X P I N F L_{i, t-1}+\mu_{i}+\varepsilon_{i, t+1}
\end{aligned}
$$

In the above equation, the dependent variable $M B_{i, t+1}$ is the market value of assets divided by the book value of assets minus trade receivables at time $t+1$, where time $t$ is the year of EPU. Our variable of interest is the interaction between EPU and TRADE CREDIT. To account for a possible nonlinear relationship between trade credit and firm value, we further include the squared term of TRADE CREDIT $T_{i, t+1}$ and its interaction with EPU. While we are agnostic about the direction of $\beta_{4}$, we expect $\beta_{5}$ to be positive to reflect the nonlinear effect of trade credit on firm value.

Regarding the control variables, $E A R N I N G S_{i, t+1}$ is the earnings before extraordinary items scaled by assets minus trade receivables at time $t+1$. EARNINGSLAG $2_{i, t+1}$ (EARNINGSFLAG2 $2_{i, t+1}$ ) is the change in the earnings levels from time $t-1$ to time $t+1$ ( $t+1$ to time $t+3)$ scaled by assets minus trade receivables at time $t+1 . \quad$ ASSETLAG $2_{i, t+1}$ (ASSETFLAG $\left.2_{i, t+1}\right)$ is the change in the asset levels from time $t-1$ to time $t+1(\mathrm{t}+1$ to time $\mathrm{t}+3)$ scaled by assets minus trade receivables at time $\mathrm{t}+1 . R D_{i, t+1}$ is research and development 
expenses at time $t+1$ scaled by assets minus trade receivables at time $\mathrm{t}+1$. $R D L A G 2_{i, t+1}$ (RDFLAG $\left.2_{i, t+1}\right)$ is the change in the $\mathrm{R} \& \mathrm{D}$ levels from time $t-1$ to time $t+1(t+1$ to time $t+3)$ scaled by assets minus trade receivables at time $t+1$. INTEREST $T_{i, t+1}$ is total interest expenses at time $t+1$ scaled by assets minus trade receivables at time $t+1$. INTERESTLAG $2_{i, t+1}$ (INTERESTFLAG2 $2_{i, t+1}$ ) is the change in the interest levels from time $t-1$ to time $t+1$ ( $t+1$ to time $t+3$ ) scaled by assets minus trade receivables at time $t+1$. DIVIDEN $D_{i, t+1}$ is total dividends paid at time $t+1$ scaled by assets minus trade receivables at time $t+1$. DIVIDENDLAG $2_{i, t+1}$ (DIVIDENDFLAG2 $2_{i, t+1}$ ) is the change in the dividend levels from time $t-1$ to time $t+1$ ( $t+1$ to time $t+3$ ) scaled by assets minus trade receivables at time $t+1 . M B F L A G 2_{i, t+1}$ is the change in $M B$ from time $t+1$ to time $t+3$ scaled by assets minus trade receivables at time $t+1 .{ }^{8}$

We further control for economic environment proxied by the following macroeconomic variables. US_CONFIDENCE is the natural logarithm of the average monthly Organization for Economic Co-operation and Development (OECD) composite confidence indicator for the U.S.; US_SENTIMENT is the natural logarithm of the average monthly University of Michigan's consumer sentiment index of the U.S.; and, US_EXPINFL is the average monthly expected inflation constructed by the University of Michigan. The term $\mu_{i}$ stands for firm fixed effects. We do not control for year fixed effects since the macroeconomic variables have the same value for all firms in a given year. We cluster the standard errors by firms.

\section{Empirical Results and Discussions}

\subsection{The impact of EPU on trade credit: baseline regressions}

\footnotetext{
${ }^{8}$ We exclude trade receivables from total assets in the denominator to avoid possible mechanical relationships between both the numerator and denominator and the dependent variable. However, the results remain robust when we do not make such subtractions. Note that no such subtraction is needed for trade payables because they are scaled by costs of goods sold.
} 
Table 3 reports the results of the baseline regressions of receivable days REC_DAYS (in Panel A), payable days PAY_DAYS (in Panel B), and the difference between receivable days and payable days NET_DAYS (in Panel C), on the natural logarithm of the composite EPU index in the last month of the preceding quarter (EPU_LAST). In model 1 of each panel, we do not control for firm and year fixed effects. In model 2 of each panel, we control for both firm and year fixed effects.

In Panel A, the coefficient on the variable EPU_LAST is negative and significant at the 1\% level across model specifications, suggesting that firms cut down on trade credit extended to their customers amid EPU. The economic effect of EPU on trade credit is also important. For illustration, since all the reported coefficients (except for the intercept) are standardized, the coefficient estimate of EPU_LAST (-0.013) in Model 1 of Panel A suggests that an increase of one standard deviation in EPU_LAST leads to a reduction of 0.013 standard deviation in REC_DAYS. In other words, a 10-point increase in EPU_LAST is associated with three days reduction in receivables. ${ }^{9}$ In Model 1 of Panel B, the coefficient on the EPU_LAST is -0.012, suggesting that a 10-point increase in EPU_LAST is associated with 9.35 days reduction in payables. In Model 1 of Panel C, a 10-point increase in EPU_MEAN is associated with 7.92 days increase in NET_DAYS. In contrast with the negative effects of EPU on REC_DAYS and PAY_DAYS, the positive effect of EPU on NET_DAYS implies that trade payables suffer from a

\footnotetext{
${ }^{9}$ The standard deviation of EPU_LAST is 0.324. The standard deviation of REC_DAYS is 33.018. An increase of 0.324 point in EPU_LAST is associated with a decrease of $0.429(0.013 \times 33.018)$ in REC_DAYS. Since EPU_LAST is the natural logarithm of the raw EPU values, a 0.324 point in EPU_LAST is equivalent to the exponential of 0.324 or 1.38-point increase in raw EPU value. A 1.38-point increase in raw EPU value is associated with 0.429 days reduction in receivables. To make the interpretation be more in line with the index's meaningful changes, we scale this 1.38-point increase in raw EPU value by a 10-point increase. Thus, a 10-point increase in raw EPU value is associated with 3.1 days reduction in receivables $(10 \times 0.429 / 1.38)$. In summary, the economic effect of EPU on trade credit is calculated as (the coefficient $\times$ standard deviation value of trade credit $\times 10$ ) / e standard deviation value of EPU.
} 
larger cut than trade receivables do and that the sample's average firm is a net credit supplier with its receivers being out of the sample, a notion consistent with Choi and Kim (2005).

\section{[INSERT TABLE 3 ABOUT HERE]}

In an alternative analysis, we rerun the baseline regressions of receivable days (REC_DAYS), payable days (PAY_DAYS), and net trade days (NET_DAYS) on the natural logarithm of the average monthly composite economic policy uncertainty index (EPU_MEAN) of the preceding quarter and other control variables. We report the results in Table IA.1 in the Internet Appendix. Consistent with the results in Table 3, the coefficient on the variable EPU_MEAN is negative and significant at the $1 \%$ level in the REC_DAYS and PAY_DAYS regressions but insignificant in the NET_DAYS regressions. In a complementary analysis, we examine the impact of news-based EPU on trade credit. The results reported in Table IA.2 in the Internet Appendix indicate that our findings are essentially similar.

\subsection{Robustness checks}

\subsubsection{The impact of EPU on trade credit policy: Do types of products traded by the firm matter?}

Giannetti et al. (2008) document that supplier trade credit varies with product characteristics. In particular, suppliers of differentiated products and services typically have larger accounts receivable than suppliers of standardized goods do. The buyers of unique inputs are less likely to default because it is harder for them to switch suppliers or resell input products (Giannetti et al., 2008; Cunat, 2007; Burkart and Ellingsen 2004), therefore, suppliers are willing

to provide more trade credit to these firms. Conversely, a customer of a standardized good supplier is likely to face low switching costs should it find changes to its current supplier's trade 
credit to be unaccommodating. The standardized nature of the product suggests that an alternative supplier can furnish it without incurring relationship-specific investments. Consistent with these arguments, previous empirical evidence demonstrates that firms trading differentiated products and service have more outstanding credit than firms trading standardized goods do (Mian and Smith, 1992; Blazenko and Vandezande, 2003; Burkart and Ellingsen, 2004; Giannetti et al., 2011; Shenoy and Williams, 2017). ${ }^{10}$ In this section, we examine whether EPU affects trade credit differently for sellers of differentiated versus standardized goods and services.

Table 4 report the results of the regressions of receivable days REC_DAYS (in Panel A), payable days PAY_DAYS (in Panel B), and net trade days NET_DAYS (in Panel C) on EPU of the last month of the preceding quarter (EPU_LAST) for subgroups of firms producing differentiated goods (Model 1), producing standardized goods (Model 2), and providing service (Model 3). In Panel A, the coefficient on the variables EPU_LAST is negative and significant only in model 2, suggesting that EPU affects receivables policy of standardized goods firms. The point estimation indicates that a 10 -point increase in EPU_LAST is associated with 3.60 days reduction in receivables for these firms. The results further suggest that the average firm selling differentiated goods in our sample does not make a significant change to its trade credit. Our evidence is consistent with Giannetti et al. (2008)'s finding that trade credit policy varies with product characteristics.

\section{[INSERT TABLE 4 ABOUT HERE]}

In Panel $\mathrm{B}$ of Table 4, the effect of EPU_LAST on payable days is negative and significant among all three subgroups of firms (-0.013, -0.016 , and -0.018 for Models 1 , 2, and 3,

\footnotetext{
${ }^{10}$ For instance, clients need longer time to test and verify the quality of non-standardized products.
} 
respectively). The Chow test statistic is 47.05 for EPU_LAST and statistically significant at the $1 \%$ level, suggesting that the impact of EPU_LAST on firm payable days is statistically different among the three subgroups. In Panel C of Table 4, the effect of EPU_LAST on net trade days NET_DAYS is positive and significant for all three subgroups, which is consistent with the results of the REC_DAYS and PAY_DAYS regressions that indicate that EPU has stronger negative effects on accounts payable than account receivables of the sample firms. Overall, while product characteristics play a role in trade credit policy, the impact of EPU is mostly significant across the product markets.

\subsubsection{The impact of EPU on trade credit policy: Does market power matter?}

In this section, we examine whether market power affects our results. Fabbri and Klapper (2008) and Dass et al. (2015) report that firms with more market power are able to obtain extended credit periods from their suppliers while granting shorter credit periods to their clients. Love and Zaidi (2010) argue that large buyers are in a position of strength to negotiate favorable credit terms with their suppliers. Dominant firms also have other means to extract rent than seeking extended credit periods for themselves-for example, by negotiating lower prices of inputs and by charging their customers more. Gonçalves et al. (2018) find that the larger the firm's market power, the faster it pays suppliers following a crisis.

Table 5 reports the results from the regressions of REC_DAYS (Panel A), PAY_DAYS (Panel B), and NET_DAYS (Panel C) on EPU_LAST for firms sorted on market power. Firms with high (low) gross profit margin are assumed to have high (low) market power. The use of the gross profit margin (also referred to as the Lerner Index) as a measure of a firm's market power is in line with Aghion et al. (2013), Dass et al. (2015), Gaspar and Massa (2006), Kale and Loon (2011), and Goncalves et al. (2018). In Panel A, the coefficient on the variable EPU_LAST is 
consistently negative and significant (-0.009) for only the subsample of firms with low market power.

\section{[INSERT TABLE 5 ABOUT HERE]}

In Panel B, the coefficient on EPU_LAST is negative and statistically significant in the payable days regressions for both low and high market power subgroups of firms and they are statistically different between the two subgroups (-0.013 for the low market power subgroup vs. 0.017 for the high market power subgroup). In Panel C, the effect of EPU_LAST on net trade days NET_DAYS is positive and significant for both subgroups, which is consistent with our finding discussed in the previous section. Although the coefficients on the EPU_LAST variable are statistically different in magnitude between the two subgroups, the evidence indicates that EPU is affecting both buyers and sellers across the market power dimension.

\subsubsection{The impact of EPU on trade credit policy: Does financial constraint matter?}

A firm's trade credit policy may depend on its financial health. For financially constrained customer firms, trade credit represents an alternative source of financing that eases their financial burden in the short term. Unlike banks, suppliers could appreciate the intricacies of the client business better and are willing to extend credit even when banks are reluctant to lend. However, suppliers can quickly repossess goods or cut supplies altogether should the buyers fail to pay. Conversely, financially constrained supplier firms would find it costlier to extend trade credit to customers (Murfin and Njoroge, 2015; Barrot, 2016). Garcia-Appendini and Montoriol-Garriga (2013) find that financially constrained firms reduced trade credit supply during the 2007-2008 crisis. 
Zhang et al. (2015) document that firms' leverage ratios are negatively related to EPU. These authors argue that due to a "supply effect," the external financing environment becomes more restrictive during times of high EPU. Furthermore, a "demand effect" could reinforce the supply effect, that is firms may choose to borrow less during times of high EPU, which is consistent with the argument that firms adopt a conservative approach during uncertain times (Bernanke, 1983b; Bloom et al., 2007).

To gauge the effect of financial constraints on the relation between EPU and trade credit, we run separate regressions for the subgroups of financially constrained and unconstrained firms. Specifically, we measure financial constraints using firm size, whether a firm is included in the S\&P 500 index, or the Whited-Wu index (Whited and Wu, 2006). The Whited-Wu index is calculated as $(-0.091 *$ operating cash flow to asset ratio $-0.062 *$ dummy for firms paying dividend in the year $+0.021 *$ long-term debt to total assets $-0.044 * \ln$ (firm assets) $+0.1021 *$ annual SIC 3-digit industry growth $-0.035 *$ firm annual growth). A firm is considered financially unconstrained (constrained) if its size is above (below) the sample median, included (not included) in the S\&P 500 index, or has Whited-Wu index value below (above) the sample median. ${ }^{11}$

In Panel A of Table 6, we report the results from the regressions of REC_DAYS, PAY_DAYS and NET_DAYS on EPU_LAST for firms sorted on financial constraints proxied by firm size. We find that higher EPU_LAST leads to lower receivable and payable days for both financially constrained and unconstrained firms. The results in Panel B of Table 6, where we use firm inclusion in the S\&P 500 index as an alternative proxy for financial constraints, are qualitatively similar. In Panel C where financial constraints are proxied by the Whited-Wu index,

${ }^{11}$ In untabulated results, we also use Hadlock-Pierce's (2010) Size and Age Index (SA) and long-term credit ratings as alternative proxies for financial constraints. The results are qualitatively similar. 
we find that the coefficient on EPU_LAST is negative and significant (insignificant) in the REC_DAYS regression for unconstrained (constrained) firms. Intuitively, it is unlikely that financially constrained firms choose to accelerate payment of their trade credit during the high EPU periods since these firms lack cash to make payment quickly; rather, pressure to shorten the payables days emanate from their suppliers. Overall, our findings that firms, financially constrained or unconstrained, curtail their trade credit are robust. Moreover, the effects of EPU on net trade days remain positive, regardless of firms’ financial conditions.

\section{[INSERT TABLE 6 ABOUT HERE]}

\subsubsection{Impact of EPU on trade credit: Do RSIs matter?}

Dass et al. (2015) argue that a supplier firm's trade credit provision is affected by its relationship-specific investment (RSI), which represents a firm's investments in sustaining its business with a specific client since the client's demands are idiosyncratic. In particular, the presence of RSI may push supplier firms to extend more credit to its buyers since the more extended credit period indicates that the supplier is committed to meeting the specific demands of the client. However, since EPU exposes the business relationship between a supplier and its client to risk, the supplier firm may be unwilling to undertake RSIs if it anticipates such a relationship to be vulnerable to EPU. In this section, we examine the relationship between EPU and trade credit, conditional on RSI.

Following Dass et al. (2015), we use the ratio of $R \& D$ expenditure-to-total assets as a proxy for RSI, with a high (low) ratio implying high (low) RSI. Allen and Phillips (2000) document that greater RSI is more likely in R\&D-intensive industries. Dass et al. (2015) argue that firms that invest more in R\&D tend to invest more in RSI. In Table 7, we sort sample firms 
into either the subgroup with high $R \& D$ expenditure (Models under A1) or the one with low R\&D expenditure (Models under A2), and perform subgroup analysis. The results in Panel A of Table 7 suggest that only low-RSI firms reduce receivable days amid high EPU. In Panels B and C of Table 7, we observe that the responsiveness of payable days and net trade days to EPU is significant and consistent in direction between low-RSI firms and high-RSI firms. This evidence suggests that the relation between EPU and trade credit is robust to controlling for RSI.

\section{[INSERT TABLE 7 ABOUT HERE]}

\subsubsection{Impact of EPU on trade credit: Does government spending matter?}

Gulen and Ion (2016), Nguyen and Phan (2017), Drobetz et al. (2018), among others, suggest that policy uncertainty might have stronger effects on firms with products dependent on government spending. Following these findings, we expect trade credit policy to be more responsive to EPU among firms whose customers are government agencies. We use Compustat Customer Segment database to identify whether a firm has government agencies as its significant customers. We then run regressions of firm trade receivables and payables separately for firms with and without government agency customers. The results reported in Table IA.3 in the Internet Appendix indicate that firms in both subsamples reduce trade credit amid EPU although the magnitude of the reduction appears to be larger among firms with government agency customers.

\subsection{Additional Robustness Checks}

The EPU index may capture the effects of general economic uncertainty, such as consumer sentiments, GDP forecast dispersion, or unexpected inflation changes. It may also capture other economic uncertainty unrelated to government policies such as labor market 
variations, oil price fluctuations, and trade-war-induced currency volatility. These observations raise concerns that our regressions could be subject to possible omitted variable and/or error-inmeasurement, which can bias our coefficient estimates. We run two tests to address these concerns.

First, to address concern with omitted variables, we follow Gulen and Ion (2016) and explicitly include the following macroeconomic factors in the regressions. US_REALGDP is the natural logarithm of the quarterly real U.S. GDP. US_EXPINFL is the expected inflation in the last month of each quarter as provided by the University of Michigan. US_CONFIDENCE is the natural logarithm of the Organization for Economic Co-operation and Development (OECD) composite confidence indicator for the U.S. in the last month of each quarter. US_SENTIMENT is the natural logarithm of the University of Michigan's U.S. consumer sentiment index in each quarter. US_MPU is the natural logarithm of the Monetary Policy Uncertainty index in the last month of each quarter as developed by Husted, Rogers and Sun (2016).

\section{[INSERT TABLE 8 ABOUT HERE]}

The regression results reported in Table 8 indicate that the macroeconomic variables explain some of the variation in trade credit. For instance, firms tend to extend receivable periods during periods of high real GDP, high consumer confidence, and high consumer sentiment as evidenced by the positive signs of US_REALGDP, US_CONFIDENT, and US_SENTIMENT. We also control for political party affiliation to account for a possibility that firms would be less affected by EPU if they are affiliated with the party of the current president. Following Sabherwal, Sarkar, and Uddin (2017), we include a dummy variable equal to 1 if both the House and the Senate are controlled by the same party and 0 otherwise. We find that the effects of EPU 
on trade credit are consistent with the results documented in Tables 3-7, suggesting that our results are not subject to the omitted variable bias.

Second, to address the possibility that the EPU index may capture other economic uncertainty unrelated to government policies, we use the News EPU Index of Canada and the Real GDP of Canada to forecast the News EPU Index in the U.S. Given the robust trade and economic relations between the U.S. and Canada (see Romalis, 2007), both countries are unlikely to be immune to each other's economic uncertainty. Therefore, the residuals are arguably a cleaner proxy for U.S. News EPU. Following this argument, we replace NEWS_EPU_LAST with NEWS_EPU_LAST_RESIDUAL and rerun the trade credit regressions. The results reported in Table 9 indicate that the coefficient of NEWS_EPU_LAST_RESIDUAL is negative and statistically significant at the $1 \%$ level in both Models 1 and 2 . Net trade days, on the other hand, are positive and statistically significant at the $1 \%$ level in Model 3, consistent with the results reported in Tables 3-8. This evidence suggests that our main findings are robust to correction for potential error-in-measurement problem. ${ }^{12}$

\section{[INSERT TABLE 9 ABOUT HERE]}

\subsection{Differential Effects of EPU and Macro-Financial Shocks on Trade Credit}

We note that Choi and Kim (2005) find positive relations between macro-financial shocks and account receivables and payables, whereas we find negative relations between EPU and these two outcome variables. While macro-financial shocks may have a direct effect on

\footnotetext{
12 Measures of the days outstanding of receivables and payables only partially explain the trade credit changes. Goncalves et al. (2018) use the dollar amounts in examining the effect of product market power on trade credit decisions during a financial crisis. Mathematically, our measures differ from theirs only in that we scale ours by assets and multiply them by the number of days of the corresponding year. However, the difference in variable construction could lead to different interpretation because days measure existing trade credit, whereas a dollar volume measures the decision to extend or not to extend the credit (see Petersen and Rajan, 1997 for a concise review of trade credit theories). To check the robustness of our results, we rerun all our regressions using the values computed as net dollar sizes. The untabulated results indicate that our findings are virtually unchanged.
} 
firms' external financing, particularly for financially constrained ones, EPU appears to have direct effects on several corporate policies including financing, investment, liquidity, and labor, among others, across the cross-section of firms as documented in the literature. To gain further insight into possible drivers of the differential effects of macro-financial shocks and EPU on trade credit, we investigate the direct relations between these uncertainties and firm cash flow volatility. Intuitively, supplier firms would be more concerned if uncertainty leads to an increase in their customers' cash flow volatility that weakens the latter's payment ability, inducing the former to curtail trade credit. We follow Nguyen and Phan (2017) to measure CASHFLOW1 as the ratio of operating income before depreciation, net of interest, taxes, and dividends to the book value of assets. Alternatively, we follow Chen et al. (2018) to measure CASHFLOW2 as earnings before extraordinary items plus depreciation and amortization deflated by sales. We then calculate the standard deviations of CASHFLOW1 and CASHFLOW2, respectively, in the four subsequent quarters and refer to them as CASHFLOWVOL1 and CASHFLOWVOL2. The regression results reported in Model 1, Panels A and B of Table 10 indicate that EPU is positively related to cash flow volatility, implying a higher trade credit risk for supplier firms.

We follow Choi and Kim (2005) and construct the macro-financial shocks variable measured by the change in Federal funds rate, which is arguably a good indicator of the Federal Reserve's policy stance. We rerun the cash flow volatility regressions on macro-financial shocks variable and other controls and report results in Model 2, Panels A and B of Table 10. Interestingly, we find that firm cash flow volatility is negatively related to macro-financial shocks. Our evidence suggests that the differential effects of macro-financial shocks and EPU on 
buyer firms' cash flow volatility trigger the observed opposite trade credit policies that reverberate throughout the supply chains. ${ }^{13}$

\section{[INSERT TABLE 10 ABOUT HERE]}

\subsection{EPU's Impact on Firm Value}

We have thus far documented that firms reduce trade credit, both accounts payable and accounts receivable, amid EPU. In this section, we investigate the value implication of such trade credit policy adjustment.

We estimate the market-to-book model and report the results in Table 11. The coefficient on REC_DAYS (Model 1) is 0.292 and significant at the $1 \%$ level, which is consistent with prior studies (e.g., Hill et al., 2015). The results suggest that, on average, extending more receivable days to the customer can increase firm value. Our calculation indicates that, holding other variables fixed at the sample means, a one-day increase in receivables is associated with $\$ 5.182$ million increase in firm market value. In Model 2, the coefficient on the PAY_DAYS variable is not statistically significant. In Model 3, the coefficient on the NET_DAYS variable is 0.192 and significant at the $1 \%$ level. A one-day increase in NET_DAYS is associated with $\$ 1.213$ million increase in firm market value.

Interestingly, the interaction terms between REC_DAYS $\times$ EPU_LAST and NET_DAYS $\times$ EPU_LAST are negative and significant, suggesting that tightening trade credit to customers during the high EPU periods are value-increasing. We interpret this finding as evidence that

\footnotetext{
${ }^{13}$ We thank an anonymous reviewer for suggestion to consider reasons for the differential effects.
} 
investors reward supplier firms’ precautionary behavior since a dollar saved or collected serves as a cushion against uncertainty. Overall, our analyses suggest that although loosening trade credit is generally positively related to firm value, doing so during the high EPU periods would adversely affect firm value.

\section{[INSERT TABLE 11 ABOUT HERE]}

Furthermore, consistent with the results reported by Martinez-Sola et al. (2013) and Hill et al. (2015), we find a nonlinear relationship between trade credit and firm value. Specifically, the coefficient on REC_DAYS_SQUARED is negative and significant, suggesting that extending trade credit has a diminishing return on receivables value. The coefficient of the interaction between REC_DAYS_SQUARED $\times$ EPU_LAST is positive and significant, which is opposite to the negative coefficients on the interaction REC_DAYS $\times$ EPU_LAST. The inverse U-shaped effect of trade credit on firm value conditional on EPU indicates that tightening trade credit is value-creating only up to a point beyond which the marginal cost of such behavior exceeds the benefit of shortening receivable days and accelerating credit collection during high EPU periods.

In a complementary analysis, we investigate whether overly tightening trade credit indeed results in the loss of customers to the competition, thereby reducing supplier firm value. We sort the sample firms into the high and low competition subgroups based on the HerfindahlHirschman index (HHI) and rerun the firm value regressions for the subgroups. HHI measures industry concentration and a low (high) value of HHI indicates high (low) industry competition. Consistent with our argument, we expect the nonlinear effect of trade credit on firm value conditional on EPU to be more pronounced for firms in highly competitive industries. The results reported in Table 12 indicate that the significance levels of the variables are higher in the subsample of firms in more competitive industries. Intuitively, in highly competitive industries, 
some supplier firms would be willing to take risk by loosening their credit supply to capture market share, thereby motivating customers to switch from their existing supplier firms that overly tighten trade credit supply amid EPU.

\section{[INSERT TABLE 12 ABOUT HERE]}

\section{Conclusions}

This study investigates the relationship between government economic policy uncertainty using the index developed by Baker et al. (2016) and trade credit, and its implication for firm value. We find robust evidence that firms curtail their receivable days during periods of high EPU. We also observe that firms face lower payable days from their suppliers during these uncertain times. Moreover, the negative effect of EPU on trade credit is consistent and broadly independent of firms’ products and services, degrees of financial constraints, market power, relationship-specific clients, and importance of sales to the government. We attribute the findings to the systemic nature of economic policy uncertainty, i.e., it tends to have profound impact on all businesses along the supply chain.

We further find that tightening credit extensions is positively related to firm value. However, we add to the literature that doing so beyond a point during periods of increasing EPU is value-decreasing. Our evidence indicates that an overly conservative trade credit policy implemented during the periods of high EPU might drive customers to competitors. Our study has important implications for corporate managers regarding firm risk and liquidity as well as policymakers on the market-wide consequences of their policy decisions. Finally, we acknowledge that our findings could be relevant for U.S. public firms but do not necessarily 
extend to private firms or foreign firms. Another limitation of our findings is related to that of the EPU index. Konczal (2012) points out that EPU may be biased upward. Thus, an avenue of future research on the impact of EPU may be fruitful in looking at trade credit policies in other world economies using different uncertainty indices. 


\section{References}

Aghion, P., Van Reenen, J., \& Zingales, L. (2013). Innovation and institutional ownership. American economic review, 103(1), 277-304.

Ahn, J., Amiti, M. and Weinstein, D.E., 2011. Trade finance and the great trade collapse. American Economic Review, 101(3), pp.298-302.

Aktas, N., De Bodt, E., Lobez, F., \& Statnik, J. C. (2012). The information content of trade credit. Journal of Banking \& Finance, 36(5), 1402-1413.

Allen, J. W., \& Phillips, G. M. (2000). Corporate equity ownership, strategic alliances, and product market relationships. The Journal of Finance, 55(6), 2791-2815.

Baker, S. R., Bloom, N., \& Davis, S. J. (2016). Measuring economic policy uncertainty. The Quarterly Journal of Economics, 131(4), 1593-1636.

Barrot, J. N. (2016). Trade credit and industry dynamics: Evidence from trucking firms. The Journal of Finance, 71(5), 1975-2016.

Baran, L., \& Dolly King, T. H. (2012). Cost of equity and S\&P 500 index revisions. Financial Management, 41(2), 457-481.

Basu, S., Bundick, B. (2014). Downside risk at the zero lower bound. Boston College, NBER, and Federal Reserve Bank of Kansas City.

Bernanke, B. S. (1983b). Non-monetary effects of the financial crisis in the propagation of the Great Depression. National Bureau of Economic Research Cambridge, MA, USA

Biais, B., \& Gollier, C. (1997). Trade credit and credit rationing. The Review of Financial Studies, 10(4), 903-937.

Blazenko, G. W., \& Vandezande, K. (2003). Corporate holding of finished goods inventories. Journal of Economics and Business, 55(3), 255-266.

Bloom, N., Bond, S. and van Reenen, J. (2007). Uncertainty and investment dynamics. Review of Economic Studies, 74, 391-415.

Boissay, F., Gropp, R., (2007). Trade credit defaults and liquidity provision by firms. European Central Bank working paper series 753.

Bonaime, A., Gulen, H. and Ion, M. (2017). Does policy uncertainty affect mergers and acquisitions? Journal of Financial Economics, Forthcoming.

Bordo, M. D., Duca, J. V., \& Koch, C. (2016). Economic policy uncertainty and the credit channel: Aggregate and bank level U.S. evidence over several decades. Journal of Financial Stability 26, 90-106.

Bougheas, S., Mateut, S., \& Mizen, P. (2009). Corporate trade credit and inventories: New evidence of a trade-off from accounts payable and receivable. Journal of Banking \& Finance, 33(2), 300-307.

Box, T., Davis, R., Hill, M., \& Lawrey, C. (2018). Operating performance and aggressive trade credit policies. Journal of Banking \& Finance, 89, 192-208.

Brennan, M. J., Maksimovics V., \& Zechner, J. (1988). Vendor financing. The Journal of Finance, 43(5), 1127-1141.

Brogaard, J. and Detzel, M. (2015). The asset pricing implications of government economic policy uncertainty, Management Science 61 (1), 3-18.

Burkart, M., Ellingsen, T., (2004). In-kind finance: a theory of trade credit. American Economic Review 94, 569-590.

Chen, R., El Ghoul, S., Guedhami, O. and Nash, R. (2018). State Ownership and Corporate Cash Holdings. Journal of Financial and Quantitative Analysis 53(5), 22932334. 
Choi, W. G., \& Kim, Y. (2005). Trade credit and the effect of macro-financial shocks: Evidence from US panel data. Journal of Financial and Quantitative Analysis, 40(4), 897-925.

Cunat, V. (2007). Trade credit: suppliers as debt collectors and insurance providers. Review of Financial Studies, 20(2), 491-527.

Dass, N., Kale, J., and Vikram, N., (2015). Trade credit, relationship-specific investment, and product market power. Review of Finance 19, 1867-1923.

Deloof, M., Jegers, M., (1996). Trade credit, product quality, and intragroup trade: some European evidence. Financial Management 25, 33-43.

Demirgüç-Kunt, A \& Maksimovic, V., 2001. Firms as financial intermediaries: Evidence from trade credit data. The World Bank.

Dittmar, A., \& Mahrt-Smith, J. (2007). Corporate governance and the value of cash holdings. Journal of Financial Economics, 83(3), 599-634.

Drobetz, W., El Ghoul, S., Guedhami, O., \& Janzen, M. (2018). Policy uncertainty, investment, and the cost of capital. Journal of Financial Stability, 39, 28-45.

Emery, G. W. (1984). A pure financial explanation for trade credit. Journal of financial and quantitative analysis, 19(3), 271-285.

Fabbri, D., \& Klapper, L. F. (2016). Bargaining power and trade credit. Journal of corporate finance, 41, 66-80.

Ferrando, A., \& Mulier, K. (2013). Do firms use the trade credit channel to manage growth? Journal of Banking \& Finance, 37(8), 3035-3046.

Ferris, J. S. (1981). A transactions theory of trade credit use. The Quarterly Journal of Economics, 96(2), 243-270.

Garcia-Appendini, E., Montoriol-Garriga, J. (2013). Firms as liquidity providers: Evidence from the 2007-2008 financial crisis. Journal of Financial Economics, 109(1), 272-291.

Gaspar, J. M., \& Massa, M. (2006). Idiosyncratic volatility and product market competition. The Journal of Business, 79(6), 3125-3152.

Giannetti, M., M. Burkart, and T. Ellingsen, 2008, "What You Sell is What You Lend? Explaining Trade Credit Contracts," Review of Financial Studies 24, 1-38.

Giannetti, M., Burkart, M., \& Ellingsen, T. (2011). What you sell is what you lend? Explaining trade credit contracts. The Review of Financial Studies, 24(4), 1261-1298.

Gilchrist, S., Sim, J. W., \& Zakrajšek, E. (2014). Uncertainty, financial frictions, and investment dynamics (No. w20038). National Bureau of Economic Research.

Gonçalves, A., Schiozer, R. and Shengb, H., (2018). Trade credit and product market power during a financial crisis. Journal of Corporate Finance 49, 308-323.

Greenwald, B. C., \& Stiglitz, J. E. (1990). Asymmetric information and the new theory of the firm: Financial constraints and risk behavior (No. w3359). National Bureau of Economic Research.

Grullon, G. and Michaely, R. (2004). The information content of share repurchase programs. Journal of Finance 59, 651-680.

Gulen, H. and Ion, M., (2016). Policy uncertainty and corporate investment. The Review of Financial Studies 29 (3), 523-564.

Hadlock, C.J. and Pierce, J.R., 2010. New evidence on measuring financial constraints: Moving beyond the KZ index. The Review of Financial Studies, 23(5), pp.1909-1940.

Hill, M.D., Kelly, G.W., Highfield, M.J., (2010). Net operating working capital behavior: a first look. Financial Management 39, 783-805. 
Husted, L. F., Rogers, J. H., \& Sun, B. (2016). Measuring Cross Country Monetary Policy Uncertainty (No. 2016-11-23). Board of Governors of the Federal Reserve System (US).

Kale, J. R., \& Loon, Y. C. (2011). Product market power and stock market liquidity. Journal of Financial Markets, 14(2), 376-410.

Kaviani, M., Kryzanowski, L., Maleki, H., \& Savor, P. G. (2017). Policy uncertainty and corporate credit spreads. Fox School of Business Research Paper, (17-020).

Kim, Y. H., \& Atkins, J. C. (1978). Evaluating investments in accounts receivable: a wealth maximizing framework. The Journal of Finance, 33(2), 403-412.

Klapper, L., Laeven, L., Rajan, R. (2012). Trade credit contracts. Review of Financial Studies 25, 838-867.

Konczal, M. (2012). What is the economic policy uncertainty index really telling us? Roosevelt Institute, Rortybomb Blog, August 8, 2012, http://rooseveltinstitute.org/what-economicpolicy-uncertainty-index-really-telling-us/

Lee, Y. W., \& Stowe, J. D. (1993). Product risk, asymmetric information, and trade credit. Journal of Financial and Quantitative analysis, 28(2), 285-300.

Long, M. S., Malitz, I. B., \& Ravid, S. A. (1993). Trade credit, quality guarantees, and product marketability. Financial management, 117-127.

Love, I., \& Zaidi, R. (2010). Trade credit, bank credit and financial crisis. International Review of Finance, 10(1), 125-147.

Martínez-Sola, C., García-Teruel, P. J., \& Martínez-Solano, P. (2013). Trade credit policy and firm value. Accounting \& Finance, 53(3), 791-808.

Matousek, R., Panopoulou, E., \& Papachristopoulou, A. (2020). Policy uncertainty and the capital shortfall of global financial firms. Journal of Corporate Finance, 101558.

Mian, L., Smith, C., (1992). Accounts receivable management policy: theory and evidence. Journal of Finance 47, 169-200.

Molina, C. A., \& Preve, L. A. (2009). Trade receivables policy of distressed firms and its effect on the costs of financial distress. Financial management, 38(3), 663-686.

Murfin, J., \& Njoroge, K. (2014). The implicit costs of trade credit borrowing by large firms. The Review of Financial Studies, 28(1), 112-145.

Nadiri, M. I. (1969). The determinants of trade credit in the US total manufacturing sector. Econometrica: Journal of the Econometric Society, 408-423.

Ng, C. K., Smith, J. K., \& Smith, R. L. (1999). Evidence on the determinants of credit terms used in interfirm trade. The journal of finance, 54(3), 1109-1129.

Nguyen, N. and Phan, H., (2017). Policy uncertainty and mergers and acquisitions. Journal of Financial and Quantitative Analysis 52 (2), 613-644.

Panousi, V. and Papanikolaou, D. (2012). Investment, idiosyncratic risk and ownership, Journal of Finance 67 (3), 1113-1148.

Pastor, L. and Veronesi, P. (2013). Political uncertainty and risk premia,” Journal of Financial Economics 110 (3), 520-545.

Petersen, M. A., \& Rajan, R. G. (1997). Trade credit: theories and evidence. The Review of Financial Studies, 10(3), 661-691.

Phan, D.H.B., Sharma, S.S. and Tran, V.T., 2018. Can economic policy uncertainty predict stock returns? Global evidence. Journal of International Financial Markets, Institutions and Money, 55, pp.134-150.

Romalis, J. (2007). NAFTA's and CUSFTA's impact on international trade. Review of Economics and Statistics 89 (3), 416-435. 
Sabherwal, S., Sarkar, S., and Uddin, M. (2017). Political party affiliation of the president, majority in the House, and sin stock returns. Financial Management, Spring, 3-31.

Sartoris, W. L., \& Hill, N. C. (1981). Evaluating credit policy alternatives: A present value framework. Journal of Financial Research, 4(1), 81-89.

Schwartz, R. A. (1974). An economic model of trade credit. Journal of Financial and Quantitative Analysis, 9(4), 643-657.

Shenoy, J., \& Williams, R. (2017). Trade credit and the joint effects of supplier and customer financial characteristics. Journal of Financial Intermediation, 29, 68-80.

Tran, D., \& Phan, H. (2020). Government economic policy uncertainty and corporate debt contracting. Working paper. Central Connecticut State University and University of Massachusetts Lowell.

Wang, X., Xu, W., \& Zhong, Z. (2019). Economic policy uncertainty, CDS spreads, and CDS liquidity provision. Journal of Futures Markets, 39 (4), 461-480.

Whited, T. M., \& Wu, G. (2006). Financial constraints risk. The Review of Financial Studies, 19(2), 531-559.

$\mathrm{Xu}, \mathrm{Z}$. (2020). Economic policy uncertainty, cost of capital, and corporate innovation. Journal of Banking \& Finance, 111, 105698.

Zhang, G., Han, J., Pan, Z., \& Huang, H. (2015). Economic policy uncertainty and capital structure choice: Evidence from China. Economic Systems, 39 (3), 439-457. 
Table 1 - Sample Distribution

We report the sample distribution by year in Panel A and by Fama-French 48-sector in Panel B.

\begin{tabular}{lll}
\hline Panel A - Distribution by Year & $\mathrm{N}$ & Percent \\
\hline 2003 & 6,241 & 2.16 \\
2004 & 20,898 & 7.24 \\
2005 & 21,416 & 7.42 \\
2006 & 21,235 & 7.35 \\
2007 & 20,741 & 7.18 \\
2008 & 20,161 & 6.98 \\
2009 & 19,420 & 6.72 \\
2010 & 19,006 & 6.58 \\
2011 & 18,391 & 6.37 \\
2012 & 18,297 & 6.34 \\
2013 & 18,064 & 6.25 \\
2014 & 18,238 & 6.31 \\
2015 & 17,763 & 6.15 \\
2016 & 16,788 & 5.81 \\
2017 & 16,180 & 5.6 \\
2018 & 15,975 & $\underline{5.53}$ \\
Total & 288,814 & 100 \\
Number of unique firms & 11,196 & \\
\hline
\end{tabular}

Panel B - Distribution by Industry

\begin{tabular}{lll} 
Industry & $\mathrm{N}$ & Percent \\
\hline Aircraft & 1,714 & 0.59 \\
Agriculture & 1,167 & 0.4 \\
Automobiles and Trucks & 4,976 & 1.72 \\
Beer \& Liquor & 1,343 & 0.47 \\
Construction Materials & 6,088 & 2.11 \\
Printing and Publishing & 1,888 & 0.65 \\
Shipping Containers & 671 & 0.23 \\
Business Services & 43,241 & 14.97 \\
Chemicals & 6,450 & 2.23 \\
Electronic Equipment & 20,531 & 7.11 \\
Apparel & 3,533 & 1.22 \\
Construction & 3,318 & 1.15 \\
Coal & 1,148 & 0.4 \\
Computers & 10,449 & 3.62 \\
Pharmaceutical Products & 24,537 & 8.5 \\
Electrical Equipment & 5,238 & 1.81 \\
Fabricated Products & 782 & 0.27 \\
Food Products & 5,214 & 1.81 \\
Entertainment & 4,553 & 1.58 \\
Precious Metals & 4,213 & 1.46 \\
Defense & 567 & 0.2 \\
Healthcare & 5,527 & 1.91 \\
Consumer Goods & 3,872 & 1.34 \\
Measuring and Control Equipment & 6,009 & 2.08 \\
Machinery & 9,567 & 3.31 \\
Restaurants, Hotels, Motels & 4,329 & 1.5 \\
Medical Equipment & 10,993 & 3.81 \\
Non-Metallic and Industrial Metal Mining & 4,295 & 1.49 \\
Petroleum and Natural Gas & 22,732 & 7.87 \\
Business Supplies & 3,033 & 1.05 \\
Personal Services & 3,434 & 1.19 \\
\hline
\end{tabular}


Retail

Rubber and Plastic Products

Shipbuilding, Railroad Equipment

Tobacco Products

Candy \& Soda

Steel Works Etc.

Communication

Recreation

Transportation

Textiles

Utilities

Wholesale

Other
12,938

2,261

617

271

1,146

3,707

11,229

2,056

9,803

660

1,878

10,124

6,712
4.48

0.78

0.21

0.09

0.4

1.28

3.89

0.71

3.39

0.23

0.65

3.51

2.32 


\section{Table 2 - Descriptive Statistics}

We report the summary statistics of the variables in this table. EPU_LAST is the natural logarithm of the last month's EPU value in each quarter. EPU_MEAN is the natural logarithm of the average monthly EPU value in each quarter. RECEIVABLES is the ratio of trade receivables to total assets minus trade receivables. ASSET is total assets minus trade receivables. PAYABLES is the ratio of trade payables to cost of goods sold. REC_DAYS is RECEIVABLES divided by the actual number of days in a year. PAY_DAYS is PAYABLE divided by the actual number of days in a year. GROSSMARGIN is the ratio of the difference between sales and cost of goods sold scaled by sales. SALE / ASSET is the ratio of sales to total assets minus trade receivables. FREE COLLATERAL is the difference between net property plant and equipment and long-term debt scaled by total assets minus trade receivables. CASH/ASSET is the ratio of cash to total assets minus trade receivables. SHORTDEBT/ASSET is the ratio of short-term debt to total assets minus trade receivables. RSI is the ratio of $\mathrm{R} \& \mathrm{D}$ expenditures to total assets minus trade receivables. $W W$ index is the Whited-Wu financial constraint index (Whited and Wu 2006), calculated as $(-0.091 *$ operating cash flow to asset ratio $-0.062 *$ dummy for firms paying dividend in the year $+0.021 *$ long-term debt to total assets $-0.044 * \ln ($ firm assets $)+0.1021 *$ annual SIC 3-digit industry growth $-0.035 *$ firm annual growth). DIFFGOODS and STDGOODS are the dummy variables for firms producing differentiated goods and firms producing standardized goods, respectively.

\begin{tabular}{|c|c|c|c|c|c|}
\hline Variables & Mean & Median & 25th percentile & 75th percentile & Standard deviation \\
\hline$E P U \_L A S T$ & 4.707 & 4.687 & 4.447 & 4.946 & 0.324 \\
\hline EPU_MEAN & 4.695 & 4.697 & 4.506 & 4.897 & 0.299 \\
\hline RECEIVABLES & 0.619 & 0.552 & 0.326 & 0.766 & 0.507 \\
\hline PAYABLES & 0.949 & 0.513 & 0.293 & 0.919 & 1.262 \\
\hline REC_DAYS & 51.975 & 49.642 & 29.364 & 68.957 & 33.018 \\
\hline PAY_DAYS & 81.452 & 46.182 & 26.384 & 82.708 & 99.528 \\
\hline$N E T \_D A Y S$ & -27.294 & -1.541 & -35.904 & 22.752 & 92.734 \\
\hline LNASSSET & -0.233 & -0.118 & -1.986 & 1.635 & 2.692 \\
\hline GROSSMARGIN & 0.245 & 0.353 & 0.189 & 0.553 & 0.597 \\
\hline SALE / ASSET & 0.344 & 0.240 & 0.118 & 0.427 & 0.382 \\
\hline FREE COLLATERAL & 0.000 & 0.000 & 0.000 & 0.002 & 0.071 \\
\hline CASH / ASSET & 0.238 & 0.139 & 0.041 & 0.363 & 0.252 \\
\hline SHORTDEBT/ASSET & 0.141 & 0.011 & 0.000 & 0.070 & 0.518 \\
\hline RSI & 0.068 & 0.000 & 0.000 & 0.028 & 0.228 \\
\hline WW index & -0.257 & -0.256 & -0.347 & -0.166 & 0.124 \\
\hline DIFFGOODS & 0.284 & 0.000 & 0.000 & 1.000 & 0.451 \\
\hline STDGOODS & 0.196 & 0.000 & 0.000 & 0.000 & 0.397 \\
\hline
\end{tabular}


Table 3 - Impact of EPU on Trade Credit Policy - EPU in the Last Month of Each Quarter

In this table, we examine the impact of EPU on firm trade credit policy. The dependent variables are REC_DAYS in Panel A, PAY_DAYS in Panel B and NET_DAYS in Panel C. RECEIVABLES is the ratio of trade receivables to total assets minus trade receivables. ASSET is total assets minus trade receivables. PAYABLES is the ratio of trade payables to cost of goods sold. REC_DAYS is RECEIVABLES divided by the actual number of days in a year. PAY_DAYS is PAYABLE divided by the actual number of days in a year. EPU_LAST is the natural logarithm of the EPU value in the last month of each quarter. GROSSMARGIN is the ratio of the difference between sales and cost of goods sold scaled by sales. SALE / ASSET is the ratio of sales to total assets minus trade receivables. FREE COLLATERAL is the difference between net property plant and equipment and long-term debt scaled by total assets minus trade receivables. CASH/ASSET is the ratio of cash to total assets minus trade receivables. SHORTDEBT/ASSET is the ratio of short-term debt to total assets minus trade receivables. RSI is the ratio of R\&D expenditures to total assets minus trade receivables. *, ** and $* * *$ indicate the significance levels of $10 \%, 5 \%$ and $1 \%$, respectively.

\begin{tabular}{|c|c|c|c|c|c|c|}
\hline \multirow[b]{2}{*}{ Variables } & \multicolumn{2}{|c|}{ Panel A - REC_DAYS } & \multicolumn{2}{|c|}{ Panel B - PAY_DAYS } & \multicolumn{2}{|c|}{ Panel C-NET_DAYS } \\
\hline & Model 1 & Model 2 & Model 1 & Model 2 & Model 1 & Model 2 \\
\hline \multirow[t]{2}{*}{ EPU_LASTt-1 } & -0.013 & -0.006 & -0.013 & -0.016 & 0.011 & 0.015 \\
\hline & $(-3.862 * * *)$ & $(-2.707 * * *)$ & $(-3.893 * * *)$ & $(-7.639 * * *)$ & $(3.134 * * *)$ & $(6.995 * * *)$ \\
\hline \multirow[t]{2}{*}{ GROSSMARGINt-1 } & 0.034 & -0.015 & 0.152 & 0.170 & -0.156 & -0.186 \\
\hline & $(4.364 * * *)$ & $(-2.342 * *)$ & $(18.260 * * *)$ & $\left(19.191^{* * *}\right)$ & $\left(-19.611^{* * *}\right)$ & $(-21.382 * * *)$ \\
\hline \multirow[t]{2}{*}{ SALE/ASSETt-1 } & -0.108 & -0.069 & -0.229 & -0.097 & 0.195 & 0.073 \\
\hline & $(-12.663 * * *)$ & $(-11.536 * * *)$ & $(-30.491 * * *)$ & $(-13.037 * * *)$ & $(26.501 * * *)$ & $\left(10.411^{* * *}\right)$ \\
\hline \multirow[t]{2}{*}{ FREE COLLATERALt-1 } & -0.008 & 0.004 & -0.019 & -0.010 & 0.015 & 0.011 \\
\hline & $(-1.540)$ & $(0.893)$ & $(-2.039 * *)$ & $\left(-1.810^{*}\right)$ & (1.589) & $(1.902 *)$ \\
\hline \multirow[t]{2}{*}{ CASH/ASSETt-1 } & 0.080 & -0.011 & -0.009 & -0.037 & 0.038 & 0.032 \\
\hline & $\left(8.911^{* * *}\right)$ & $(-1.476)$ & $(-1.073)$ & $(-4.969 * * *)$ & $\left(4.415^{* * *}\right)$ & $\left(4.208^{* * *}\right)$ \\
\hline \multirow[t]{2}{*}{ SHORTDEBT/ASSETt-1 } & 0.017 & -0.015 & 0.319 & 0.101 & -0.302 & -0.100 \\
\hline & $(2.555 * *)$ & $(-2.532 * *)$ & $\left(38.283^{* * *}\right)$ & $\left(13.191^{* * *}\right)$ & $(-37.423 * * *)$ & $(-13.589 * * *)$ \\
\hline \multirow[t]{2}{*}{ RSIt-1 } & -0.042 & -0.017 & 0.071 & 0.027 & -0.097 & -0.034 \\
\hline & $(-4.709 * * *)$ & $(-2.227 * *)$ & $(6.464 * * *)$ & $(3.292 * * *)$ & $(-9.202 * * *)$ & $(-4.166 * * *)$ \\
\hline \multirow[t]{2}{*}{ Constant } & 58.916 & 58.035 & 103.664 & 106.402 & -43.664 & -45.647 \\
\hline & $(35.836 * * *)$ & $(54.497 * * *)$ & $(20.877 * * *)$ & $\left(32.842^{* * *}\right)$ & $(-9.475 * * *)$ & $\left(-14.615^{* * *}\right)$ \\
\hline R-squared & 0.017 & 0.680 & 0.131 & 0.693 & 0.116 & 0.683 \\
\hline Adj. R-squared & 0.0169 & 0.666 & 0.130 & 0.680 & 0.116 & 0.670 \\
\hline Firm fixed effect & No & Yes & No & Yes & No & Yes \\
\hline Year fixed effect & No & Yes & No & Yes & No & Yes \\
\hline Clustered std err by firm & Yes & Yes & Yes & Yes & Yes & Yes \\
\hline Observations & 273,397 & 274,363 & 273,397 & 274,363 & 273,397 & 274,363 \\
\hline
\end{tabular}


Table 4 - Impact of EPU on Trade Credit Policy - By Firm Types

In this table, we examine the impact of EPU on firm trade credit policy by each firm type. Firms are classified by their types of products including (1) Differentiated Goods, (2) Standardized Goods and (3) Services. The dependent variables are REC_DAYS in Panel A, PAY_DAYS in Panel B and NET_DAYS in Panel C. RECEIVABLES is the ratio of trade receivables to total assets minus trade receivables. ASSET is total assets minus trade receivables. PAYABLES is the ratio of trade payables to cost of goods sold. REC_DAYS is RECEIVABLES divided by the actual number of days in a year. PAY_DAYS is PAYABLE divided by the actual number of days in a year. EPU_LAST is the natural logarithm of the last month's EPU value in each quarter. GROSSMARGIN is the ratio of the difference between sales and cost of goods sold scaled by sales. SALE / ASSET is the ratio of sales to total assets minus trade receivables. FREE COLLATERAL is the difference between net property plant and equipment and long-term debt scaled by total assets minus trade receivables. CASH/ASSET is the ratio of cash to total assets minus trade receivables. SHORTDEBT/ASSET is the ratio of short-term debt to total assets minus trade receivables. RSI is the ratio of R\&D expenditures to total assets minus trade receivables. *, ** and *** indicate the significance levels of $10 \%, 5 \%$ and $1 \%$, respectively.

\begin{tabular}{|c|c|c|c|c|c|c|c|c|c|}
\hline \multirow[b]{3}{*}{ Variables } & \multicolumn{3}{|c|}{ Panel A - REC_DAYS } & \multicolumn{3}{|c|}{ Panel B - PAY_DAYS } & \multicolumn{3}{|c|}{ Panel C - NET_DAYS } \\
\hline & $\begin{array}{l}\text { Model } 1 \\
\text { Differentiated }\end{array}$ & $\begin{array}{l}\text { Model } 2 \\
\text { Standardized }\end{array}$ & Model 3 & $\begin{array}{l}\text { Model } 1 \\
\text { Differentiated }\end{array}$ & $\begin{array}{l}\text { Model } 2 \\
\text { Standardized }\end{array}$ & Model 3 & $\begin{array}{l}\text { Model } 1 \\
\text { Differentiated }\end{array}$ & $\begin{array}{l}\text { Model } 2 \\
\text { Standardized }\end{array}$ & Model 3 \\
\hline & Goods & Goods & Services & Goods & Goods & Services & Goods & Goods & Services \\
\hline EPU_LASTt-1 & $\begin{array}{l}-0.007 \\
(-1.590)\end{array}$ & $\begin{array}{l}-0.015 \\
(-2.584 * * *)\end{array}$ & $\begin{array}{l}-0.002 \\
(-0.801)\end{array}$ & $\begin{array}{l}-0.013 \\
\left(-2.893^{* * *}\right)\end{array}$ & $\begin{array}{l}-0.016 \\
\left(-3.378^{* * *}\right)\end{array}$ & $\begin{array}{l}-0.018 \\
(-6.319 * * *)\end{array}$ & $\begin{array}{l}0.012 \\
(2.762 * * *)\end{array}$ & $\begin{array}{l}0.012 \\
\left(2.362^{* *}\right)\end{array}$ & $\begin{array}{l}0.018 \\
\left(6.113^{* * *}\right)\end{array}$ \\
\hline $\begin{array}{l}\text { GROSSMARGINt- } \\
1\end{array}$ & -0.017 & & & & & & & & -0.131 \\
\hline 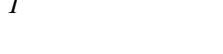 & $\begin{array}{l}-0.017 \\
(-1.369)\end{array}$ & $\begin{array}{l}-0.004 \\
(-0.210)\end{array}$ & $\begin{array}{l}-0.018 \\
\left(-2.488^{* *}\right)\end{array}$ & $\left(8.810^{* * *}\right)$ & $\begin{array}{l}0.308 \\
\left(13.017^{* * *}\right)\end{array}$ & $\begin{array}{l}0.108 \\
\left(11.611^{* * *}\right)\end{array}$ & $\begin{array}{l}-0.178 \\
\left(-9.255^{* * *}\right)\end{array}$ & $\begin{array}{l}-0.310 \\
\left(-12.975^{* * *}\right)\end{array}$ & $\begin{array}{l}-0.131 \\
\left(-14.418^{* * *}\right)\end{array}$ \\
\hline SALE/ASSETt-1 & $\begin{array}{l}-0.051 \\
(-4.826 * * *)\end{array}$ & $\begin{array}{l}-0.071 \\
(-5.961 * * *)\end{array}$ & $\begin{array}{l}-0.077 \\
\left(-8.983^{* * *}\right)\end{array}$ & $\begin{array}{l}-0.087 \\
(-7.059 * * *)\end{array}$ & $\begin{array}{l}-0.109 \\
(-9.241 * * *)\end{array}$ & $\begin{array}{l}-0.097 \\
(-8.617 * * *)\end{array}$ & $\begin{array}{l}0.069 \\
(5.937 * * *)\end{array}$ & $\begin{array}{l}0.085 \\
\left(7.633^{* * *}\right)\end{array}$ & $\begin{array}{l}0.070 \\
(6.649 * * *)\end{array}$ \\
\hline FREE & 0.009 & -0.001 & 0.004 & -0.022 & -0.009 & -0.005 & 0.025 & 0.004 & 0.007 \\
\hline COLLATERALt-1 & $(1.060)$ & $(-0.066)$ & $(0.650)$ & $\left(-1.776^{*}\right)$ & $(-0.768)$ & $(-0.631)$ & $(2.016 * *)$ & $(0.335)$ & $(0.856)$ \\
\hline CASH/ASSETt-1 & $\begin{array}{l}-0.025 \\
(-1.906 *)\end{array}$ & $\begin{array}{l}-0.010 \\
(-0.514)\end{array}$ & $\begin{array}{l}-0.007 \\
(-0.762)\end{array}$ & $\begin{array}{l}-0.077 \\
\left(-4.693^{* * *}\right)\end{array}$ & $\begin{array}{l}-0.052 \\
\left(-2.375^{* *}\right)\end{array}$ & $\begin{array}{l}-0.020 \\
(-2.332 * *)\end{array}$ & $\begin{array}{l}0.066 \\
(3.958 * * *)\end{array}$ & $\begin{array}{l}0.047 \\
\left(2.133^{* *}\right)\end{array}$ & $\begin{array}{l}0.016 \\
\left(1.830^{*}\right)\end{array}$ \\
\hline SHORTDEBT/ASS & -0.032 & -0.025 & -0.007 & 0.122 & 0.126 & 0.083 & -0.128 & -0.124 & -0.082 \\
\hline ETt-1 & $\left(-2.512^{* *}\right)$ & $\left(-1.875^{*}\right)$ & $(-0.874)$ & $\left(7.161^{* * *}\right)$ & $\left(8.166^{* * *}\right)$ & $(7.967 * * *)$ & $\left(-7.825^{* * *}\right)$ & $(-8.010 * * *)$ & $(-8.199 * * *)$ \\
\hline RSIt-1 & $\begin{array}{l}0.005 \\
(0.464)\end{array}$ & $\begin{array}{l}-0.045 \\
(-2.229 * *)\end{array}$ & $\begin{array}{l}-0.006 \\
(-0.750)\end{array}$ & $\begin{array}{l}0.068 \\
\left(4.496^{* * *}\right)\end{array}$ & $\begin{array}{l}0.017 \\
(0.902)\end{array}$ & $\begin{array}{l}0.026 \\
\left(2.533^{* *}\right)\end{array}$ & $\begin{array}{l}-0.069 \\
(-4.544 * * *)\end{array}$ & $\begin{array}{l}-0.033 \\
\left(-1.761^{*}\right)\end{array}$ & $\begin{array}{l}-0.027 \\
\left(-2.663^{* * *}\right)\end{array}$ \\
\hline Constant & $\begin{array}{l}65.886 \\
\left(36.157^{* * *}\right)\end{array}$ & $\begin{array}{l}55.659 \\
\left(19.644^{* * *}\right)\end{array}$ & $\begin{array}{l}54.809 \\
\left(37.831^{* * *}\right)\end{array}$ & $\begin{array}{l}89.886 \\
\left(16.326^{* * *}\right)\end{array}$ & $\begin{array}{l}108.136 \\
\left(14.589^{* * *}\right)\end{array}$ & $\begin{array}{l}117.447 \\
\left(24.851^{* * *}\right)\end{array}$ & $\begin{array}{l}-22.971 \\
\left(-4.374^{* * *}\right)\end{array}$ & $\begin{array}{l}-50.037 \\
\left(-7.134^{* * *}\right)\end{array}$ & $\begin{array}{l}-58.302 \\
\left(-12.646^{* * *}\right)\end{array}$ \\
\hline R-squared & 0.603 & 0.553 & 0.734 & 0.645 & 0.674 & 0.712 & 0.646 & 0.650 & 0.699 \\
\hline Adj. R-squared & 0.589 & 0.534 & 0.722 & 0.632 & 0.660 & 0.699 & 0.633 & 0.635 & 0.686 \\
\hline Firm fixed effect & Yes & Yes & Yes & Yes & Yes & Yes & Yes & Yes & Yes \\
\hline Year fixed effect & Yes & Yes & Yes & Yes & Yes & Yes & Yes & Yes & Yes \\
\hline $\begin{array}{l}\text { Clustered std err } \\
\text { by firm }\end{array}$ & Yes & Yes & Yes & Yes & Yes & Yes & Yes & Yes & Yes \\
\hline Observations & 78,604 & 53,773 & 141,986 & 78,604 & 53,773 & 141,986 & 78,604 & 53,773 & 141,986 \\
\hline
\end{tabular}


Table 5 - Impact of EPU on Trade Credit Policy - Firms with Low Gross Margin vs. Firms with High Gross Margin

In this table, we examine the impact of EPU on firm trade credit policy separately for the subsample of firms with low gross margin and the subsample of firms with high gross margin. The dependent variables are REC_DAYS in Panel A, PAY_DAYS in Panel B and NET_DAYS in Panel C. RECEIVABLES is the ratio of trade receivables to total assets minus trade receivables. ASSET is total assets minus trade receivables. PAYABLES is the ratio of trade payables to cost of goods sold. REC DAYS is RECEIVABLES divided by the actual number of days in a year. PAY DAYS is PAYABLE divided by the actual number of days in a year EPU_LAST is the natural logarithm of the last month's EPU value in each quarter. GROSSMARGIN is the ratio of the difference between sales and cost of goods sold scaled by sales. SALE / ASSET is the ratio of sales to total assets minus trade receivables. FREE COLLATERAL is the difference between net property plant and equipment and long-term debt scaled by total assets minus trade receivables. CASH/ASSET is the ratio of cash to total assets minus trade receivables. SHORTDEBT/ASSET is the ratio of short-term debt to total assets minus trade receivables. RSI is the ratio of R\&D expenditures to total assets minus trade receivables. *, ** and ${ }^{* * *}$ indicate the significance levels of $10 \%, 5 \%$ and $1 \%$, respectively.

\begin{tabular}{|c|c|c|c|c|c|c|}
\hline \multirow[b]{2}{*}{ Variables } & \multicolumn{2}{|c|}{ Panel A - Receivable Days (REC_DAYS) } & \multicolumn{2}{|c|}{ Panel B - Payable Days (PAY_DAYS) } & \multicolumn{2}{|c|}{ Panel C - Net Days (NET_DAYS) } \\
\hline & $\begin{array}{l}\text { Model } 1 \text { - Low } \\
\text { Gross Margin }\end{array}$ & $\begin{array}{l}\text { Model } 2 \text { - High } \\
\text { Gross Margin }\end{array}$ & $\begin{array}{l}\text { Model } 1 \text { - Low Gross } \\
\text { Margin }\end{array}$ & $\begin{array}{l}\text { Model } 2 \text { - High Gross } \\
\text { Margin }\end{array}$ & $\begin{array}{l}\text { Model } 1 \text { - Low Gross } \\
\text { Margin }\end{array}$ & $\begin{array}{l}\text { Model } 2 \text { - High Gross } \\
\text { Margin }\end{array}$ \\
\hline EPU_LASTt-1 & $\begin{array}{l}-0.009 \\
(-2.849 * * *)\end{array}$ & $\begin{array}{l}-0.001 \\
(-0.223)\end{array}$ & $\begin{array}{l}-0.013 \\
(-3.849 * * *)\end{array}$ & $\begin{array}{l}-0.017 \\
(-6.090 * * *)\end{array}$ & $\begin{array}{l}0.009 \\
\left(2.558^{* *}\right)\end{array}$ & $\begin{array}{l}0.018 \\
\left(6.304^{* * *}\right)\end{array}$ \\
\hline GROSSMARGINt-1 & $\begin{array}{l}-0.037 \\
(-4.130 * * *)\end{array}$ & $\begin{array}{l}0.004 \\
(0.424)\end{array}$ & $\begin{array}{l}0.060 \\
(4.799 * * *)\end{array}$ & $\begin{array}{l}0.158 \\
(17.867 * * *)\end{array}$ & $\begin{array}{l}-0.090 \\
(-7.140 * * *)\end{array}$ & $\begin{array}{l}-0.160 \\
(-18.302 * * *)\end{array}$ \\
\hline SALE/ASSETt-1 & $\begin{array}{l}-0.060 \\
\left(-7.528^{* * *}\right)\end{array}$ & $\begin{array}{l}-0.066 \\
\left(-9.034^{* * *}\right)\end{array}$ & $\begin{array}{l}-0.094 \\
(-7.938 * * *)\end{array}$ & $\begin{array}{l}-0.059 \\
(-8.982 * * *)\end{array}$ & $\begin{array}{l}0.067 \\
\left(5.857^{* * *}\right)\end{array}$ & $\begin{array}{l}0.040 \\
\left(5.985^{* * *}\right)\end{array}$ \\
\hline FREE COLLATERALt-1 & $\begin{array}{l}0.006 \\
(1.073)\end{array}$ & $\begin{array}{l}-0.001 \\
(-0.102)\end{array}$ & $\begin{array}{l}-0.017 \\
(-1.817 *)\end{array}$ & $\begin{array}{l}-0.007 \\
(-1.054)\end{array}$ & $\begin{array}{l}0.021 \\
(2.126 * *)\end{array}$ & $\begin{array}{l}0.005 \\
(0.843)\end{array}$ \\
\hline CASH/ASSETt-1 & $\begin{array}{l}-0.001 \\
(-0.068)\end{array}$ & $\begin{array}{l}-0.022 \\
(-2.247 * *)\end{array}$ & $\begin{array}{l}-0.054 \\
\left(-4.575^{* * *}\right)\end{array}$ & $\begin{array}{l}-0.041 \\
(-4.938 * * *)\end{array}$ & $\begin{array}{l}0.052 \\
(4.236 * * *)\end{array}$ & $\begin{array}{l}0.033 \\
\left(4.004^{* * *}\right)\end{array}$ \\
\hline SHORTDEBT/ASSETt-1 & $\begin{array}{l}-0.023 \\
(-2.847 * * *)\end{array}$ & $\begin{array}{l}-0.004 \\
(-0.483)\end{array}$ & $\begin{array}{l}0.130 \\
\left(11.506^{* * *}\right)\end{array}$ & $\begin{array}{l}0.062 \\
\left(6.708^{* * *}\right)\end{array}$ & $\begin{array}{l}-0.137 \\
\left(-12.216^{* * *}\right)\end{array}$ & $\begin{array}{l}-0.057 \\
\left(-6.361^{* * *}\right)\end{array}$ \\
\hline RSIt-1 & $\begin{array}{l}-0.022 \\
\left(-2.105^{* *}\right)\end{array}$ & $\begin{array}{l}-0.011 \\
(-1.195)\end{array}$ & $\begin{array}{l}-0.004 \\
(-0.423)\end{array}$ & $\begin{array}{l}0.045 \\
\left(4.970^{* * *}\right)\end{array}$ & $\begin{array}{l}-0.009 \\
(-0.884)\end{array}$ & $\begin{array}{l}-0.045 \\
\left(-5.195^{* * *}\right)\end{array}$ \\
\hline Constant & $\begin{array}{l}57.825 \\
\left(34.345^{* * *}\right)\end{array}$ & $\begin{array}{l}56.650 \\
\left(32.902^{* * *}\right)\end{array}$ & $\begin{array}{l}87.340 \\
\left(20.478^{* * *}\right)\end{array}$ & $\begin{array}{l}69.751 \\
\left(11.460^{* * *}\right)\end{array}$ & $\begin{array}{l}-24.347 \\
(-6.139 * * *)\end{array}$ & $\begin{array}{l}-14.012 \\
\left(-2.434^{* *}\right)\end{array}$ \\
\hline R-squared & 0.675 & 0.727 & 0.653 & 0.757 & 0.630 & 0.753 \\
\hline Adj. R-squared & 0.654 & 0.711 & 0.631 & 0.743 & 0.607 & 0.739 \\
\hline Firm fixed effect & Yes & Yes & Yes & Yes & Yes & Yes \\
\hline Year fixed effect & Yes & Yes & Yes & Yes & Yes & Yes \\
\hline Clustered std err by firm & Yes & Yes & Yes & Yes & Yes & Yes \\
\hline Observations & 136,968 & 137,395 & 136,968 & 137,395 & 136,968 & 137,395 \\
\hline
\end{tabular}


Table 6 - Impact of EPU on Trade Credit Days - Firms with Low Financial Constraints vs. Firms with High Financial Constraints

RECEIVABLES is the ratio of trade receivables to total assets minus trade receivables. ASSET is total assets minus trade receivables. PAYABLES is the ratio of trade payables to cost of goods sold. REC_DAYS is RECEIVABLES divided by the actual number of days in a year. PAY_DAYS is PAYABLE divided by the actual number of days in a year. EPU_LAST is the natural logarithm of the last month's EPU value in each quarter. GROSSMARGIN is the ratio of the difference between sales and cost of goods sold scaled by sales. SALE / ASSET is the ratio of sales to total assets minus trade receivables. FREE COLLATERAL is the difference between net property plant and equipment and long-term debt scaled by total assets minus trade receivables. CASH/ASSET is the ratio of cash to total assets minus trade receivables. SHORTDEBT/ASSET is the ratio of short-term debt to total assets minus trade receivables. $R S I$ is the ratio of R\&D expenditures to total assets minus trade receivables. *, ** and *** indicate the significance levels of $10 \%, 5 \%$ and $1 \%$, respectively.

\begin{tabular}{|c|c|c|c|c|c|c|}
\hline \multicolumn{6}{|c|}{ Panel A - Small firms vs. Large Firms } & Panel A3 - Net Days (NET_DAYS) \\
\hline 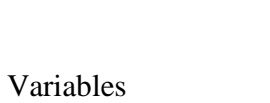 & Model 1-Small firms & Model 2-Large firms & Model 1- Small firms & Model 2-Large firms & Model 1-Small firms & $\begin{array}{l}\text { Model 2-Large } \\
\text { firms }\end{array}$ \\
\hline EPU_LASTt-1 & $\begin{array}{l}-0.007 \\
(-1.937)\end{array}$ & $\begin{array}{l}-0.005 \\
(-2.090 *)\end{array}$ & $\begin{array}{l}-0.012 \\
\left(-3.720^{* *}\right)\end{array}$ & $\begin{array}{l}-0.024 \\
(-8.259 * *)\end{array}$ & $\begin{array}{l}0.011 \\
\left(3.478^{* *}\right)\end{array}$ & $\begin{array}{l}0.023 \\
\left(7.640^{* *}\right)\end{array}$ \\
\hline GROSSMARGINt-1 & $\begin{array}{l}-0.014 \\
(-1.604)\end{array}$ & $\begin{array}{l}-0.022 \\
\left(-3.361^{* *}\right)\end{array}$ & $\begin{array}{l}0.185 \\
\left(16.154^{* *}\right)\end{array}$ & $\begin{array}{l}0.120 \\
(10.523 * *)\end{array}$ & $\begin{array}{l}-0.199 \\
(-17.898 * *)\end{array}$ & $\begin{array}{l}-0.138 \\
\left(-12.065^{* *}\right)\end{array}$ \\
\hline SALE/ASSETt-1 & $\begin{array}{l}-0.058 \\
(-7.773 * *)\end{array}$ & $\begin{array}{l}-0.115 \\
(-10.186 * *)\end{array}$ & $\begin{array}{l}-0.095 \\
(-10.269 * *)\end{array}$ & $\begin{array}{l}-0.115 \\
(-8.779 * *)\end{array}$ & $\begin{array}{l}0.077 \\
\left(8.828^{* *}\right)\end{array}$ & $\begin{array}{l}0.066 \\
\left(5.714^{* *}\right)\end{array}$ \\
\hline FREE & & & & & & \\
\hline COLLATERALt-1 & $\begin{array}{l}0.005 \\
(0.891)\end{array}$ & $\begin{array}{l}0.010 \\
(1.242)\end{array}$ & $\begin{array}{l}-0.012 \\
(-1.680)\end{array}$ & $\begin{array}{l}0.026 \\
\left(4.283^{* *}\right)\end{array}$ & $\begin{array}{l}0.013 \\
(1.852)\end{array}$ & $\begin{array}{l}-0.017 \\
(-1.733)\end{array}$ \\
\hline CASH/ASSETt-1 & $\begin{array}{l}-0.002 \\
(-0.231)\end{array}$ & $\begin{array}{l}-0.028 \\
\left(-2.763^{* *}\right)\end{array}$ & $\begin{array}{l}-0.055 \\
\left(-5.688^{* *}\right)\end{array}$ & $\begin{array}{l}-0.000 \\
(-0.012)\end{array}$ & $\begin{array}{l}0.052 \\
\left(5.450^{* *}\right)\end{array}$ & $\begin{array}{l}-0.013 \\
(-1.434)\end{array}$ \\
\hline SHORTDEBT/ASS & & & & & & \\
\hline ETt-1 & $\begin{array}{l}-0.025 \\
(-3.161 * *)\end{array}$ & $\begin{array}{l}0.014 \\
(3.194 * *)\end{array}$ & $\begin{array}{l}0.120 \\
\left(12.513^{* *}\right)\end{array}$ & $\begin{array}{l}0.004 \\
(0.880)\end{array}$ & $\begin{array}{l}-0.122 \\
\left(-13.363^{* *}\right)\end{array}$ & $\begin{array}{l}0.004 \\
(0.735)\end{array}$ \\
\hline RSIt-1 & $\begin{array}{l}-0.019 \\
(-1.933)\end{array}$ & $\begin{array}{l}-0.015 \\
(-0.928)\end{array}$ & $\begin{array}{l}0.036 \\
\left(3.483^{* *}\right)\end{array}$ & $\begin{array}{l}0.010 \\
(0.904)\end{array}$ & $\begin{array}{l}-0.044 \\
\left(-4.268^{* *}\right)\end{array}$ & $\begin{array}{l}-0.016 \\
(-1.231)\end{array}$ \\
\hline Constant & $\begin{array}{l}61.723 \\
\left(23.336^{* *}\right)\end{array}$ & $\begin{array}{l}58.860 \\
(38.199 * *)\end{array}$ & $\begin{array}{l}121.464 \\
\left(16.650^{* *}\right)\end{array}$ & $\begin{array}{l}84.546 \\
\left(18.820^{* *}\right)\end{array}$ & $\begin{array}{l}-57.725 \\
\left(-8.102^{* *}\right)\end{array}$ & $\begin{array}{l}-23.438 \\
\left(-5.376^{* *}\right)\end{array}$ \\
\hline R-squared & 0.608 & 0.814 & 0.673 & 0.747 & 0.662 & 0.748 \\
\hline Adj. R-squared & 0.586 & 0.807 & 0.655 & 0.736 & 0.642 & 0.738 \\
\hline Firm fixed effect & Yes & Yes & Yes & Yes & Yes & Yes \\
\hline $\begin{array}{l}\text { Year fixed effects } \\
\text { Clustered std err by }\end{array}$ & Yes & Yes & Yes & Yes & Yes & Yes \\
\hline firm & Yes & Yes & Yes & Yes & Yes & Yes \\
\hline Observations & 130,569 & 133,061 & 130,569 & 133,061 & 130,569 & 133,061 \\
\hline
\end{tabular}


Panel B - Firms Included in the S\&P 500 Index vs. Firms not Included in the S\&P 500 Index

\begin{tabular}{|c|c|c|c|c|c|c|}
\hline \multirow[b]{2}{*}{ Variables } & \multicolumn{2}{|c|}{ Panel B1 - Receivable Days (REC_DAYS) } & \multicolumn{2}{|c|}{ Panel B2 - Payable Days (PAY_DAYS) } & \multicolumn{2}{|c|}{ Panel B3 - Net Days (NET_DAYS) } \\
\hline & Model 1-SP500 firms & $\begin{array}{l}\text { Model 2-Non-SP500 } \\
\text { firms }\end{array}$ & Model 1-SP500 firms & $\begin{array}{l}\text { Model 2-Non-SP500 } \\
\text { firms }\end{array}$ & Model 1-SP500 firms & $\begin{array}{l}\text { Model 2-Non- } \\
\text { SP500 firms }\end{array}$ \\
\hline EPU_LASTt-1 & $\begin{array}{l}-0.015 \\
(-3.317 * *)\end{array}$ & $\begin{array}{l}-0.005 \\
(-2.307 *)\end{array}$ & $\begin{array}{l}-0.039 \\
(-5.041 * *)\end{array}$ & $\begin{array}{l}-0.015 \\
(-6.692 * *)\end{array}$ & $\begin{array}{l}0.032 \\
\left(4.348^{* *}\right)\end{array}$ & $\begin{array}{l}0.014 \\
(6.222 * *)\end{array}$ \\
\hline R-squared & 0.844 & 0.671 & 0.736 & 0.691 & 0.756 & 0.680 \\
\hline Adj. R-squared & 0.838 & 0.657 & 0.727 & 0.678 & 0.748 & 0.666 \\
\hline Control variables & Yes & Yes & Yes & Yes & Yes & Yes \\
\hline Firm fixed effect & Yes & Yes & Yes & Yes & Yes & Yes \\
\hline Year fixed effects & Yes & Yes & Yes & Yes & Yes & Yes \\
\hline Clustered std err by & & & & & & \\
\hline firm & Yes & Yes & Yes & Yes & Yes & Yes \\
\hline Observations & 20,503 & 253,860 & 20,503 & 253,860 & 20,503 & 253,860 \\
\hline
\end{tabular}

Panel C - Firms with Low Whited-Wu Index vs. Firms with High Whited-Wu Index Panel C1 - Receivable Days (REC_DAYS) Panel C2 - Payable Days (PAY_DAYS)

Panel C3 - Net Days (NET_DAYS)

\begin{tabular}{|c|c|c|c|c|c|c|}
\hline Variables & $\begin{array}{l}\text { Model 1- Low Whited- } \\
\text { Wu Index }\end{array}$ & $\begin{array}{l}\text { Model 2- High Whited- } \\
\text { Wu Index }\end{array}$ & $\begin{array}{l}\text { Model 1- Low Whited- } \\
\text { Wu Index }\end{array}$ & $\begin{array}{l}\text { Model 2- High Whited- } \\
\text { Wu Index }\end{array}$ & $\begin{array}{l}\text { Model 1- Low } \\
\text { Whited-Wu } \\
\text { Index }\end{array}$ & $\begin{array}{l}\text { Model 2- High } \\
\text { Whited-Wu } \\
\text { Index }\end{array}$ \\
\hline$E P U \_L A S T t-1$ & $\begin{array}{l}-0.006 \\
(-2.394 *)\end{array}$ & $\begin{array}{l}-0.005 \\
(-1.452)\end{array}$ & $\begin{array}{l}-0.021 \\
\left(-7.009^{* *}\right)\end{array}$ & $\begin{array}{l}-0.014 \\
\left(-4.415^{* *}\right)\end{array}$ & $\begin{array}{l}0.019 \\
\left(6.408^{* *}\right)\end{array}$ & $\begin{array}{l}0.014 \\
(4.269 * *)\end{array}$ \\
\hline R-squared & 0.608 & 0.814 & 0.673 & 0.747 & 0.662 & 0.748 \\
\hline Adj. R-squared & 0.800 & 0.595 & 0.736 & 0.660 & 0.737 & 0.650 \\
\hline Control variables & Yes & Yes & Yes & Yes & Yes & Yes \\
\hline Firm fixed effect & Yes & Yes & Yes & Yes & Yes & Yes \\
\hline Year fixed effects & Yes & Yes & Yes & Yes & Yes & Yes \\
\hline Clustered std err by firm & Yes & Yes & Yes & Yes & Yes & Yes \\
\hline Observations & 132,746 & 131,077 & 132,746 & 131,077 & 132,746 & 131,077 \\
\hline
\end{tabular}


Table 7 - Impact of EPU on Net Trade Credit Days - Firms with Low vs. Firms with High Relationship-Specific Investment Effects

In this table, we examine the impact of EPU on firm trade credit policy separately for the subsample of firms with low relationship-specific investment and the subsample of firms with high relationship-specific investment. We use the R\&D expenses to asset ratio as a proxy for financial constraints. The dependent variables are REC_DAYS in Panel A, PAY_DAYS in Panel B and NET_DAYS in Panel C. RECEIVABLES is the ratio of trade receivables to total assets minus trade receivables. ASSET is total assets minus trade receivables. PAYABLES is the ratio of trade payables to cost of goods sold. REC_DAYS is RECEIVABLES divided by the actual number of days in a year. PAY_DAYS is PAYABLE divided by the actual number of days in a year. EPU_LAST is the natural logarithm of the last month's EPU value in each quarter. GROSSMARGIN is the ratio of the difference between sales and cost of goods sold scaled by sales. SALE / ASSET is the ratio of sales to total assets minus trade receivables. FREE COLLATERAL is the difference between net property plant and equipment and long-term debt scaled by total assets minus trade receivables. CASH/ASSET is the ratio of cash to total assets minus trade receivables. SHORTDEBT/ASSET is the ratio of short-term debt to total assets minus trade receivables. $R S I$ is the ratio of R\&D expenditures to total assets minus trade receivables. ${ }^{*}, * *$ and ${ }^{* * *}$ indicate the significance levels of $10 \%, 5 \%$ and $1 \%$, respectively.

\begin{tabular}{|c|c|c|c|c|c|c|}
\hline \multirow[b]{3}{*}{ Variables } & \multicolumn{2}{|c|}{ Panel A - Receivable Days (REC_DAYS) } & \multicolumn{2}{|c|}{ Panel B - Payable Days (PAY_DAYS) } & \multicolumn{2}{|c|}{ Panel C - Net Days (NET_DAYS) } \\
\hline & Model 1-Low & Model 2-High & Model 1-Low & Model 2-High & Model 1-Low & Model 2-High \\
\hline & $\begin{array}{l}\text { Relationship Specific } \\
\text { Investment }\end{array}$ & $\begin{array}{l}\text { Relationship Specific } \\
\text { Investment }\end{array}$ & $\begin{array}{l}\text { Relationship Specific } \\
\text { Investment }\end{array}$ & $\begin{array}{l}\text { Relationship Specific } \\
\text { Investment }\end{array}$ & $\begin{array}{l}\text { Relationship Specific } \\
\text { Investment }\end{array}$ & $\begin{array}{l}\text { Relationship Specific } \\
\text { Investment }\end{array}$ \\
\hline \multirow[t]{2}{*}{ EPU_LASTt-1 } & -0.008 & -0.003 & -0.017 & -0.014 & 0.016 & 0.014 \\
\hline & $(-3.244 * *)$ & $(-0.708)$ & $\left(-6.333^{* *}\right)$ & $(-4.083 * *)$ & $\left(5.717^{* *}\right)$ & $\left(3.915^{* *}\right)$ \\
\hline \multirow[t]{2}{*}{ GROSSMARGINt-1 } & -0.024 & -0.003 & 0.083 & 0.288 & -0.109 & -0.280 \\
\hline & $(-3.891 * *)$ & $(-0.248)$ & $(10.458 * *)$ & $(15.892 * *)$ & $\left(-14.115^{* *}\right)$ & $(-15.950 * *)$ \\
\hline \multirow[t]{2}{*}{ SALE/ASSETt-1 } & -0.072 & -0.059 & -0.098 & -0.095 & 0.072 & 0.074 \\
\hline & $\left(-8.721^{* *}\right)$ & $\left(-7.554^{* *}\right)$ & $(-9.291 * *)$ & $(-11.129 * *)$ & $(7.354 * *)$ & $\left(9.044^{* *}\right)$ \\
\hline \multirow[t]{2}{*}{ FREE COLLATERALt-1 } & 0.006 & -0.003 & -0.008 & -0.014 & 0.010 & 0.010 \\
\hline & (1.177) & $(-0.465)$ & $(-0.980)$ & $(-1.686)$ & $(1.277)$ & $(1.265)$ \\
\hline \multirow[t]{2}{*}{ CASH/ASSETt-1 } & 0.011 & -0.029 & -0.006 & -0.072 & 0.011 & 0.057 \\
\hline & $(1.265)$ & $\left(-2.678^{* *}\right)$ & $(-0.739)$ & $(-6.541 * *)$ & $(1.374)$ & $\left(5.127^{* *}\right)$ \\
\hline \multirow[t]{2}{*}{ SHORTDEBT/ASSETt-1 } & -0.010 & -0.019 & 0.097 & 0.096 & -0.096 & -0.095 \\
\hline & $(-1.191)$ & $(-2.148 *)$ & $\left(10.715^{* *}\right)$ & $\left(7.425^{* *}\right)$ & $(-10.644 * *)$ & $(-8.037 * *)$ \\
\hline \multirow[t]{2}{*}{ RSIt-1 } & & -0.023 & & 0.069 & & -0.074 \\
\hline & & $(-1.778)$ & & $\left(5.077^{* *}\right)$ & & $(-5.579 * *)$ \\
\hline \multirow[t]{2}{*}{ Constant } & 47.293 & 51.999 & 90.547 & 77.572 & -38.302 & -23.943 \\
\hline & $(25.660 * *)$ & $(20.328 * *)$ & $\left(15.331^{* *}\right)$ & $(10.770 * *)$ & $\left(-7.004^{* *}\right)$ & $\left(-3.505^{* *}\right)$ \\
\hline R-squared & 0.738 & 0.584 & 0.726 & 0.663 & 0.712 & 0.664 \\
\hline Adj. R-squared & 0.726 & 0.563 & 0.713 & 0.646 & 0.698 & 0.647 \\
\hline Firm fixed effect & Yes & Yes & Yes & Yes & Yes & Yes \\
\hline Year fixed effect & Yes & Yes & Yes & Yes & Yes & Yes \\
\hline Clustered std err by firm & Yes & Yes & Yes & Yes & Yes & Yes \\
\hline Observations & 160,363 & 114,000 & 160,363 & 114,000 & 160,363 & 114,000 \\
\hline
\end{tabular}


Table 8 - Impact of EPU on Trade Credit Days - Omitted variables

RECEIVABLES is the ratio of trade receivables to total assets minus trade receivables. ASSET is total assets minus trade receivables. PAYABLES is the ratio of trade payables to cost of goods sold. REC_DAYS is RECEIVABLES divided by the actual number of days in a year. PAY_DAYS is PAYABLE divided by the actual number of days in a year. EPU_LAST is the natural logarithm of the EPU value in the last month of each quarter. US_REALGDP is the natural logarithm of the quarterly real GDP in the US. US_EXPINFL is the expected inflation in the last month of each quarter as provided by University of Michigan. US_CONFIDENCE is the natural logarithm of the composite confidence indicator for US in the last month of each quarter as provided by OECD. US_SENTIMENT is the natural logarithm of the consumer sentiment index in the US in the last month of each quarter as provided by University of Michigan. MPU is the natural logarithm of the monetary policy uncertainty in the last month of each quarter. ELECTION YEAR is the dummy variable equal to 1 for presidential election years and 0 otherwise. HOUSE vs. SENATE is the dummy variable equal to 1 if both the House and the Senate are controlled by the same party and 0 otherwise. GROSSMARGIN is the ratio of the difference between sales and cost of goods sold scaled by sales. SALE / ASSET is the ratio of sales to total assets minus trade receivables. FREE COLLATERAL is the difference between net property plant and equipment and long-term debt scaled by total assets minus trade receivables. CASH/ASSET is the ratio of cash to total assets minus trade receivables. SHORTDEBT/ASSET is the ratio of short-term debt to total assets minus trade receivables. RSI is the ratio of R\&D expenditures to total assets minus trade receivables. *, ** and *** indicate the significance levels of $10 \%, 5 \%$ and $1 \%$, respectively.

\begin{tabular}{|c|c|c|c|c|c|}
\hline \multicolumn{6}{|c|}{ Panel A - Dependent variable $=$ REC_DAYS } \\
\hline Variables & Model 1 & Model 2 & Model 3 & Model 4 & Model 5 \\
\hline EPU_LASTt-1 & $\begin{array}{l}-0.008 \\
\left(-3.511^{* *}\right)\end{array}$ & $\begin{array}{l}-0.009 \\
\left(-4.037^{* *}\right)\end{array}$ & $\begin{array}{l}-0.017 \\
(-6.692 * *)\end{array}$ & $\begin{array}{l}-0.016 \\
\left(-6.827^{* *}\right)\end{array}$ & $\begin{array}{l}-0.013 \\
\left(-4.161^{* *}\right)\end{array}$ \\
\hline US_REALGDPt-1 & $\begin{array}{l}0.011 \\
\left(2.636^{* *}\right)\end{array}$ & $\begin{array}{l}0.012 \\
(2.809 * *)\end{array}$ & & & $\begin{array}{l}0.005 \\
(1.186)\end{array}$ \\
\hline US_EXPINFLt-1 & $\begin{array}{l}-0.000 \\
(-0.242)\end{array}$ & $\begin{array}{l}-0.001 \\
(-0.711)\end{array}$ & & & $\begin{array}{l}-0.006 \\
(-3.189 * *)\end{array}$ \\
\hline US_CONFIDENCEt-1 & $\begin{array}{l}0.012 \\
(3.597 * *)\end{array}$ & & & & $\begin{array}{l}0.046 \\
(3.449 * *)\end{array}$ \\
\hline US_SENTIMENTt-1 & & $\begin{array}{l}0.010 \\
\left(3.368^{* *}\right)\end{array}$ & & & $\begin{array}{l}-0.036 \\
(-3.093 * *)\end{array}$ \\
\hline MPUt-1 & & & $\begin{array}{l}0.007 \\
\left(4.023^{* *}\right)\end{array}$ & & $\begin{array}{l}0.002 \\
(1.451)\end{array}$ \\
\hline ELECTION YEAR & & & & $\begin{array}{l}0.001 \\
(0.862)\end{array}$ & $\begin{array}{l}0.003 \\
(1.940)\end{array}$ \\
\hline HOUSE VS. SENATE & & & & $\begin{array}{l}0.006 \\
\left(3.317^{* *}\right)\end{array}$ & $\begin{array}{l}0.011 \\
(4.889 * *)\end{array}$ \\
\hline GROSSMARGINt-1 & $\begin{array}{l}-0.015 \\
(-2.379 *)\end{array}$ & $\begin{array}{l}-0.015 \\
\left(-2.383^{*}\right)\end{array}$ & $\begin{array}{l}-0.014 \\
(-2.182 *)\end{array}$ & $\begin{array}{l}-0.014 \\
\left(-2.278^{*}\right)\end{array}$ & $\begin{array}{l}-0.014 \\
\left(-2.184^{*}\right)\end{array}$ \\
\hline SALE/ASSETt-1 & $\begin{array}{l}-0.068 \\
\left(-11.428^{* *}\right)\end{array}$ & $\begin{array}{l}-0.068 \\
\left(-11.423^{* *}\right)\end{array}$ & $\begin{array}{l}-0.071 \\
\left(-11.643^{* *}\right)\end{array}$ & $\begin{array}{l}-0.070 \\
\left(-11.753^{* *}\right)\end{array}$ & $\begin{array}{l}-0.070 \\
\left(-11.471^{* *}\right)\end{array}$ \\
\hline FREE COLLATERALt-1 & $\begin{array}{l}0.004 \\
(0.917)\end{array}$ & $\begin{array}{l}0.004 \\
(0.920)\end{array}$ & $\begin{array}{l}0.002 \\
(0.545)\end{array}$ & $\begin{array}{l}0.004 \\
(0.858)\end{array}$ & $\begin{array}{l}0.003 \\
(0.588)\end{array}$ \\
\hline CASH/ASSETt-1 & $\begin{array}{l}-0.011 \\
(-1.500)\end{array}$ & $\begin{array}{l}-0.011 \\
(-1.498)\end{array}$ & $\begin{array}{l}-0.012 \\
(-1.572)\end{array}$ & $\begin{array}{l}-0.013 \\
(-1.745)\end{array}$ & $\begin{array}{l}-0.010 \\
(-1.398)\end{array}$ \\
\hline SHORTDEBT/ASSETt-1 & $\begin{array}{l}-0.015 \\
\left(-2.591^{* *}\right)\end{array}$ & $\begin{array}{l}-0.015 \\
\left(-2.593^{* *}\right)\end{array}$ & $\begin{array}{l}-0.015 \\
\left(-2.365^{*}\right)\end{array}$ & $\begin{array}{l}-0.015 \\
\left(-2.431^{*}\right)\end{array}$ & $\begin{array}{l}-0.015 \\
\left(-2.435^{*}\right)\end{array}$ \\
\hline RSIt-1 & $\begin{array}{l}-0.017 \\
\left(-2.208^{*}\right)\end{array}$ & $\begin{array}{l}-0.017 \\
\left(-2.211^{*}\right)\end{array}$ & $\begin{array}{l}-0.015 \\
(-1.877)\end{array}$ & $\begin{array}{l}-0.017 \\
(-2.242 *)\end{array}$ & $\begin{array}{l}-0.015 \\
(-1.902)\end{array}$ \\
\hline Constant & $\begin{array}{l}-120.720 \\
\left(-3.294^{* *}\right)\end{array}$ & $\begin{array}{l}-2.892 \\
(-0.156)\end{array}$ & $\begin{array}{l}60.888 \\
(52.954 * *)\end{array}$ & $\begin{array}{l}62.666 \\
\left(53.484^{* *}\right)\end{array}$ & $\begin{array}{l}-461.127 \\
\left(-3.197^{* *}\right)\end{array}$ \\
\hline R-squared & 0.679 & 0.679 & 0.684 & 0.679 & 0.684 \\
\hline Adj. R-squared & 0.666 & 0.666 & 0.670 & 0.665 & 0.671 \\
\hline Firm fixed effects & Yes & Yes & Yes & Yes & Yes \\
\hline Clustered std err by firm & Yes & Yes & Yes & Yes & Yes \\
\hline
\end{tabular}




\begin{tabular}{|c|c|c|c|c|c|}
\hline Observations & 274,363 & 274,363 & 255,231 & 274,363 & 255,231 \\
\hline \multicolumn{6}{|c|}{ Panel B - Dependent variable $=$ PAY_DAYS } \\
\hline Variables & Modelel 1 & Model 2 & Model 3 & Model 4 & Model 5 \\
\hline EPU_LASTt-1 & $\begin{array}{l}-0.009 \\
\left(-4.020^{* *}\right)\end{array}$ & $\begin{array}{l}-0.009 \\
(-4.027 * *)\end{array}$ & $\begin{array}{l}-0.008 \\
(-3.259 * *)\end{array}$ & $\begin{array}{l}-0.008 \\
\left(-3.586^{* *}\right)\end{array}$ & $\begin{array}{l}-0.011 \\
\left(-3.868^{* *}\right)\end{array}$ \\
\hline US_REALGDPt-1 & $\begin{array}{l}0.001 \\
(0.334)\end{array}$ & $\begin{array}{l}0.001 \\
(0.317)\end{array}$ & & & $\begin{array}{l}0.002 \\
(0.474)\end{array}$ \\
\hline US_EXPINFLt-1 & $\begin{array}{l}-0.007 \\
\left(-4.465^{* *}\right)\end{array}$ & $\begin{array}{l}-0.007 \\
(-4.467 * *)\end{array}$ & & & $\begin{array}{l}-0.010 \\
\left(-5.788^{* *}\right)\end{array}$ \\
\hline US_CONFIDENCEt-1 & $\begin{array}{l}-0.003 \\
(-0.868)\end{array}$ & & & & $\begin{array}{l}0.003 \\
(0.196)\end{array}$ \\
\hline US_SENTIMENTt-1 & & $\begin{array}{l}-0.003 \\
(-0.889)\end{array}$ & & & $\begin{array}{l}-0.004 \\
(-0.355)\end{array}$ \\
\hline MPUt-1 & & & $\begin{array}{l}-0.003 \\
(-1.558)\end{array}$ & & $\begin{array}{l}-0.003 \\
(-1.894)\end{array}$ \\
\hline ELECTION YEAR & & & & $\begin{array}{l}0.002 \\
(1.605)\end{array}$ & $\begin{array}{l}0.004 \\
\left(2.870^{* *}\right)\end{array}$ \\
\hline HOUSE VS. SENATE & & & & $\begin{array}{l}0.001 \\
(0.517)\end{array}$ & $\begin{array}{l}0.006 \\
\left(2.869^{* *}\right)\end{array}$ \\
\hline Constant & $\begin{array}{l}174.873 \\
(1.616)\end{array}$ & $\begin{array}{l}90.723 \\
(1.786)\end{array}$ & $\begin{array}{l}96.418 \\
\left(28.209^{* *}\right)\end{array}$ & $\begin{array}{l}94.447 \\
(26.538 * *)\end{array}$ & $\begin{array}{l}0.291 \\
(0.001)\end{array}$ \\
\hline R-squared & 0.692 & 0.692 & 0.696 & 0.692 & 0.696 \\
\hline Adj. R-squared & 0.679 & 0.679 & 0.683 & 0.679 & 0.683 \\
\hline Control variables & Yes & Yes & Yes & Yes & Yes \\
\hline Firm fixed effects & Yes & Yes & Yes & Yes & Yes \\
\hline Clustered std err by firm & Yes & Yes & Yes & Yes & Yes \\
\hline Observations & 274,363 & 274,363 & 255,231 & 274,363 & 255,231 \\
\hline \multicolumn{6}{|c|}{ Panel C - Dependent variable $=$ NET_DAYS } \\
\hline Variables & Modelel 1 & Model 2 & Model 3 & Model 4 & Model 5 \\
\hline EPU_LASTt-1 & $\begin{array}{l}0.008 \\
(3.372 * *)\end{array}$ & $\begin{array}{l}0.007 \\
\left(3.177^{* *}\right)\end{array}$ & $\begin{array}{l}0.003 \\
(1.332)\end{array}$ & $\begin{array}{l}0.004 \\
(1.507)\end{array}$ & $\begin{array}{l}0.009 \\
(2.882 * *)\end{array}$ \\
\hline US_REALGDPt-1 & $\begin{array}{l}0.003 \\
(0.653)\end{array}$ & $\begin{array}{l}0.003 \\
(0.743)\end{array}$ & & & $\begin{array}{l}0.000 \\
(0.017)\end{array}$ \\
\hline US_EXPINFLt-1 & $\begin{array}{l}0.007 \\
(4.708 * *)\end{array}$ & $\begin{array}{l}0.007 \\
(4.519 * *)\end{array}$ & & & $\begin{array}{l}0.008 \\
(4.742 * *)\end{array}$ \\
\hline US_CONFIDENCEt-1 & $\begin{array}{l}0.007 \\
(2.358 *)\end{array}$ & & & & $\begin{array}{l}0.019 \\
(1.479)\end{array}$ \\
\hline US_SENTIMENTt-1 & & $\begin{array}{l}0.007 \\
\left(2.274^{*}\right)\end{array}$ & & & $\begin{array}{l}-0.013 \\
(-1.154)\end{array}$ \\
\hline MPUt-1 & & & $\begin{array}{l}0.006 \\
\left(3.201^{* *}\right)\end{array}$ & & $\begin{array}{l}0.004 \\
\left(2.435^{*}\right)\end{array}$ \\
\hline ELECTION YEAR & & & & $\begin{array}{l}-0.001 \\
(-0.718)\end{array}$ & $\begin{array}{l}-0.002 \\
(-1.810)\end{array}$ \\
\hline HOUSE VS. SENATE & & & & $\begin{array}{l}0.002 \\
(0.968)\end{array}$ & $\begin{array}{l}-0.002 \\
(-0.817)\end{array}$ \\
\hline Constant & $\begin{array}{l}-301.832 \\
\left(-3.018^{* *}\right)\end{array}$ & $\begin{array}{l}-91.796 \\
(-1.917)\end{array}$ & $\begin{array}{l}-33.260 \\
(-10.399 * *)\end{array}$ & $\begin{array}{l}-29.260 \\
\left(-8.880^{* *}\right)\end{array}$ & $\begin{array}{l}-633.391 \\
(-1.595)\end{array}$ \\
\hline R-squared & 0.683 & 0.683 & 0.687 & 0.683 & 0.687 \\
\hline Adj. R-squared & 0.670 & 0.670 & 0.673 & 0.670 & 0.673 \\
\hline Control variables & Yes & Yes & Yes & Yes & Yes \\
\hline Firm fixed effects & Yes & Yes & Yes & Yes & Yes \\
\hline Clustered std err by firm & Yes & Yes & Yes & Yes & Yes \\
\hline Observations & 274,363 & 274,363 & 255,231 & 274,363 & 255,231 \\
\hline
\end{tabular}


Table 9 - Impact of EPU on Trade Credit Days - Endogeneity \& Canada Policy Uncertainty Index

RECEIVABLES is the ratio of trade receivables to total assets minus trade receivables. ASSET is total assets minus trade receivables. PAYABLES is the ratio of trade payables to cost of goods sold. REC_DAYS is RECEIVABLES divided by the actual number of days in a year. PAY_DAYS is PAYABLE divided by the actual number of days in a year. NEWS_EPU_MEAN_RESIDUAL is the average monthly residuals in each year obtained from the regression of the monthly US news-based economic policy uncertainty index on Canada news-based economic policy uncertainty index and Canada real GDP. GROSSMARGIN is the ratio of the difference between sales and cost of goods sold scaled by sales. SALE / ASSET is the ratio of sales to total assets minus trade receivables. FREE COLLATERAL is the difference between net property plant and equipment and long-term debt scaled by total assets minus trade receivables. CASH/ASSET is the ratio of cash to total assets minus trade receivables. SHORTDEBT/ASSET is the ratio of short-term debt to total assets minus trade receivables. $R S I$ is the ratio of R\&D expenditures to total assets minus trade receivables. *, ** and *** indicate the significance levels of $10 \%, 5 \%$ and $1 \%$, respectively.

\begin{tabular}{llll}
\hline & Model 1 & Model 2 & Model 3 \\
Variables & REC_DAYS & PAY_DAYS & NET_DAYS \\
\hline NEWS_EPU_RESIDUAL & -0.004 & -0.012 & 0.010 \\
& $\left(-3.359^{* * *}\right)$ & $\left(-9.808^{* * *}\right)$ & $\left(8.375^{* * *}\right)$ \\
GROSSMARGINt-1 & -0.015 & 0.170 & -0.186 \\
& $\left(-2.359^{* *}\right)$ & $\left(19.136^{* * *}\right)$ & $\left(-21.392^{* * *}\right)$ \\
SALE/ASSETt-1 & -0.069 & -0.097 & 0.073 \\
& $\left(-11.537^{* * *}\right)$ & $\left(-13.011^{* * *}\right)$ & $\left(10.434^{* * *}\right)$ \\
FREE COLLATERALt-1 & 0.004 & -0.010 & 0.011 \\
& $(0.897)$ & $\left(-1.800^{*}\right)$ & $\left(1.898^{*}\right)$ \\
CASH/ASSETt-1 & -0.011 & -0.037 & 0.032 \\
& $(-1.472)$ & $\left(-4.939^{* * *}\right)$ & $\left(4.219^{* * *}\right)$ \\
SHORTDEBT/ASSETt-1 & -0.015 & 0.102 & -0.100 \\
& $\left(-2.530^{* *}\right)$ & $\left(13.148^{* * *}\right)$ & $\left(-13.593^{* * *}\right)$ \\
RSIt-1 & -0.017 & 0.028 & -0.034 \\
& $\left(-2.229^{* *}\right)$ & $\left(3.304^{* * *}\right)$ & $\left(-4.156^{* * *}\right)$ \\
Constant & 55.312 & 83.619 & -25.173 \\
& $\left(105.163^{* * *}\right)$ & $\left(51.505^{* * *}\right)$ & $\left(-16.834^{* * *}\right)$ \\
R-squared & 0.679 & 0.692 & 0.683 \\
Adj. R-squared & 0.666 & 0.679 & 0.670 \\
Firm fixed effects & Yes & Yes & Yes \\
Year fixed effects & Yes & Yes & Yes \\
Clustered std err by firm & Yes & Yes & Yes \\
Observations & 274,363 & 274,363 & 274,363 \\
\hline
\end{tabular}


Table 10 - Impact of Economic Policy Uncertainty and Macro-Financial Shocks on Cash Flow Volatility In this table, we examine the impact of economic policy uncertainty and macro-financial shocks on firm cash flow volatility. The dependent variables are CASHFLOW1VOL in Panel A and CASHFLOW2VOL in Panel B, respectively. CASHFLOW1 is the ratio of operating income before depreciation, net of interest, taxes, and dividends to the book value of assets. Alternatively, CASHFLOW2 is earnings before extraordinary items plus depreciation and amortization deflated by sales. We then calculate the standard deviations of CASHFLOW1 and CASHFLOW2, respectively, in the four subsequent quarters and refer to them as CASHFLOWVOL1 and CASHFLOWVOL2. EPU_LAST is the natural log of the composite economic policy uncertainty index and newsbased economic policy uncertainty index in the last month of each quarter. FFCHG_LAST is the quarterly change of the Fed Funds rate. LNASSETS is the natural logarithm of total assets at time t. EARNINGS is the earnings before extraordinary items scaled by assets minus trade receivables at time $t+1$. EARNINGS is the earnings levels from time $t$ scaled by assets minus trade receivables at time $t$. US_SENTIMENT is the natural logarithm of the consumer sentiment index in the US in the last month of each quarter as provided by University of Michigan. US_CONFIDENCE is the natural logarithm of the composite confidence indicator for US in the last month of each quarter as provided by OECD. US_EXPINFL is the expected inflation in the last month of each quarter as provided by University of Michigan. *, ** and *** indicate the significance levels of $10 \%, 5 \%$ and $1 \%$, respectively.

\begin{tabular}{|c|c|c|c|c|}
\hline \multirow[b]{2}{*}{ Variables } & \multicolumn{2}{|c|}{ Panel A - CASHFLOW1VOL } & \multicolumn{2}{|c|}{ Panel B - CASHFLOW2VOL } \\
\hline & Model 1 & Model 2 & Model 1 & Model 2 \\
\hline$E P U \_L A S T$ & $\begin{array}{l}0.025 \\
\left(8.126^{* * *}\right)\end{array}$ & & $\begin{array}{l}0.023 \\
\left(7.505^{* * *}\right)\end{array}$ & \\
\hline FFCHG_LAST & & $\begin{array}{l}-0.016 \\
(-8.179 * * *)\end{array}$ & & $\begin{array}{l}-0.020 \\
(-9.287 * * *)\end{array}$ \\
\hline LNASSETt & $\begin{array}{l}-0.546 \\
(-18.340 * * *)\end{array}$ & $\begin{array}{l}-0.540 \\
\left(-18.365^{* * *}\right)\end{array}$ & $\begin{array}{l}-0.427 \\
\left(-14.678^{* * *}\right)\end{array}$ & $\begin{array}{l}-0.422 \\
(-14.714 * * *)\end{array}$ \\
\hline EARNINGSt & $\begin{array}{l}-0.144 \\
(-24.250 * * *)\end{array}$ & $\begin{array}{l}-0.145 \\
\left(-24.365^{* * *}\right)\end{array}$ & $\begin{array}{l}-0.133 \\
\left(-21.826^{* * *}\right)\end{array}$ & $\begin{array}{l}-0.134 \\
(-21.954 * * *)\end{array}$ \\
\hline US_SENTIMENTt-1 & $\begin{array}{l}-0.048 \\
(-3.654 * * *)\end{array}$ & $\begin{array}{l}-0.003 \\
(-0.262)\end{array}$ & $\begin{array}{l}-0.049 \\
\left(-3.365^{* * *}\right)\end{array}$ & $\begin{array}{l}0.000 \\
(0.012)\end{array}$ \\
\hline US_CONFIDENCEt-1 & $\begin{array}{l}0.065 \\
\left(4.306^{* * *}\right)\end{array}$ & $\begin{array}{l}0.010 \\
(0.739)\end{array}$ & $\begin{array}{l}0.057 \\
\left(3.457^{* * *}\right)\end{array}$ & $\begin{array}{l}0.002 \\
(0.116)\end{array}$ \\
\hline US_EXPINFLt-1 & $\begin{array}{l}0.004 \\
(2.067 * *)\end{array}$ & $\begin{array}{l}-0.003 \\
\left(-1.775^{*}\right)\end{array}$ & $\begin{array}{l}0.006 \\
\left(2.841^{* * *}\right)\end{array}$ & $\begin{array}{l}-0.001 \\
(-0.554)\end{array}$ \\
\hline Constant & $\begin{array}{l}-2.931 \\
(-4.139 * * *)\end{array}$ & $\begin{array}{l}-0.309 \\
(-0.470)\end{array}$ & $\begin{array}{l}-4.691 \\
\left(-3.311^{* * *}\right)\end{array}$ & $\begin{array}{l}0.127 \\
(0.095)\end{array}$ \\
\hline R-squared & 0.691 & 0.693 & 0.646 & 0.646 \\
\hline Adj. R-squared & 0.678 & 0.677 & 0.631 & 0.631 \\
\hline Firm fixed effects & Yes & Yes & Yes & Yes \\
\hline Clustered std. err. by firm & Yes & Yes & Yes & Yes \\
\hline Observations & 267,682 & 267,682 & 267,687 & 267,687 \\
\hline
\end{tabular}




\section{Table 11 - Impact on Firm Value}

In this table, we examine the impact of EPU and trade credit policy on firm value. The dependent variable MB is the market value of assets divided by the book value of assets minus trade receivables at time $t+1$, where time $t$ is the year of EPU. RECEIVABLES is the ratio of trade receivables to total assets minus trade receivables. ASSET is total assets minus trade receivables. PAYABLES is the ratio of trade payables to cost of goods sold. REC_DAYS is RECEIVABLES divided by the actual number of days in a year. PAY_DAYS is PAYABLE divided by the actual number of days in a year. EPU_LAST is the natural log of the composite economic policy uncertainty index and news-based economic policy uncertainty index in the last month of each quarter. EARNINGS is the earnings before extraordinary items scaled by assets minus trade receivables at time $t+1$. EARNINGSLAG2 (EARNINGSFLAG2) is the change in the earnings levels from time $\mathrm{t}-1$ to time $\mathrm{t}+1(\mathrm{t}+1$ to time $t+3$ ) scaled by assets minus trade receivables at time $t+1$. ASSETLAG2 (ASSETFLAG2) is the change in the asset levels from time $\mathrm{t}-1$ to time $\mathrm{t}+1(\mathrm{t}+1$ to time $\mathrm{t}+3)$ scaled by assets minus trade receivables at time $\mathrm{t}+1$. $\mathrm{RD}$ is research and development expenses at time $\mathrm{t}+1$ scaled by assets minus trade receivables at time $\mathrm{t}+1$. RDLAG2 (RDFLAG2) is the change in the R\&D levels from time $t-1$ to time $t+1(t+1$ to time $t+3$ ) scaled by assets minus trade receivables at time $t+1$. INTEREST is total interest expenses at time $t+1$ scaled by assets minus trade receivables at time $t+1$. INTERESTLAG2 (INTERESTFLAG2) is the change in the interest levels from time $\mathrm{t}-1$ to time $\mathrm{t}+1(\mathrm{t}+1$ to time $\mathrm{t}+3)$ scaled by assets minus trade receivables at time $\mathrm{t}+1$. DIVIDENDS is total dividends paid at time $\mathrm{t}+1$ scaled by assets minus trade receivables at time $\mathrm{t}+1$. DIVIDENDSLAG2 (DIVIDENDSFLAG2) is the change in the dividend levels from time $t-1$ to time $t+1(t+1$ to time $t+3)$ scaled by assets minus trade receivables at time $t+1$. MBFLAG2 is the change in MB from time $t+1$ to time $t+3$ scaled by assets minus trade receivables at time $t+1$. US_SENTIMENT is the natural logarithm of the consumer sentiment index in the US in the last month of each quarter as provided by University of Michigan. US_CONFIDENCE is the natural logarithm of the composite confidence indicator for US in the last month of each quarter as provided by OECD. US_EXPINFL is the expected inflation in the last month of each quarter as provided by University of Michigan. *, ** and *** indicate the significance levels of $10 \%, 5 \%$ and $1 \%$, respectively.

\begin{tabular}{|c|c|c|c|c|}
\hline Variables & Model 1 & Model 2 & Model 3 & Model 4 \\
\hline EPU_LAST & $\begin{array}{l}-0.017 \\
(-2.379 * *)\end{array}$ & $\begin{array}{l}-0.045 \\
\left(-9.165^{* * *}\right)\end{array}$ & $\begin{array}{l}-0.042 \\
(-13.340 * * *)\end{array}$ & $\begin{array}{l}-0.025 \\
(-3.172 * * *)\end{array}$ \\
\hline REC_DAYS & $\begin{array}{l}0.292 \\
(2.578 * * *)\end{array}$ & & & $\begin{array}{l}0.262 \\
\left(2.305^{* *}\right)\end{array}$ \\
\hline$R E C \_D A Y S \times E P U \_L A S T$ & $\begin{array}{l}-0.349 \\
\left(-3.136^{* * *}\right)\end{array}$ & & & $\begin{array}{l}-0.317 \\
(-2.837 * * *)\end{array}$ \\
\hline$R E C \_D A Y S^{2}$ & $\begin{array}{l}-0.254 \\
\left(-2.267^{* *}\right)\end{array}$ & & & $\begin{array}{l}-0.191 \\
\left(-1.693^{*}\right)\end{array}$ \\
\hline$R E C \_D A Y S^{2} \times E P U \_L A S T$ & $\begin{array}{l}0.271 \\
\left(2.448^{* *}\right)\end{array}$ & & & $\begin{array}{l}0.202 \\
\left(1.817^{*}\right)\end{array}$ \\
\hline PAY_DAYS & & $\begin{array}{l}-0.063 \\
(-0.495)\end{array}$ & & $\begin{array}{l}-0.139 \\
(-1.072)\end{array}$ \\
\hline$P A Y \_D A Y S \times E P U \_L A S T$ & & $\begin{array}{l}0.044 \\
(0.351)\end{array}$ & & $\begin{array}{l}0.138 \\
(1.076)\end{array}$ \\
\hline$P A Y \_D A Y S^{2}$ & & $\begin{array}{l}-0.071 \\
(-0.571)\end{array}$ & & $\begin{array}{l}0.000 \\
(0.002)\end{array}$ \\
\hline$P A Y \_D A Y S^{2} \times E P U \_L A S T$ & & $\begin{array}{l}0.106 \\
(0.851)\end{array}$ & & $\begin{array}{l}0.024 \\
(0.190)\end{array}$ \\
\hline NET_DAYS & & & $\begin{array}{l}0.192 \\
(2.469 * *)\end{array}$ & \\
\hline$N E T \_D A Y S \times E P U \_L A S T$ & & & $\begin{array}{l}-0.234 \\
(-2.964 * * *)\end{array}$ & \\
\hline$N E T \_D A Y S^{2}$ & & & $\begin{array}{l}0.054 \\
(0.695)\end{array}$ & \\
\hline$N E T \_D A Y S^{2} \times E P U \_L A S T$ & & & $\begin{array}{l}-0.067 \\
(-0.859)\end{array}$ & \\
\hline EARNINGS & $\begin{array}{l}-0.133 \\
\left(-14.123^{* * *}\right)\end{array}$ & $\begin{array}{l}-0.131 \\
\left(-14.001^{* * *}\right)\end{array}$ & $\begin{array}{l}-0.131 \\
(-14.012 * * *)\end{array}$ & $\begin{array}{l}-0.132 \\
(-14.179 * * *)\end{array}$ \\
\hline EARNINGSLAG2 & 0.035 & 0.036 & 0.035 & 0.034 \\
\hline
\end{tabular}




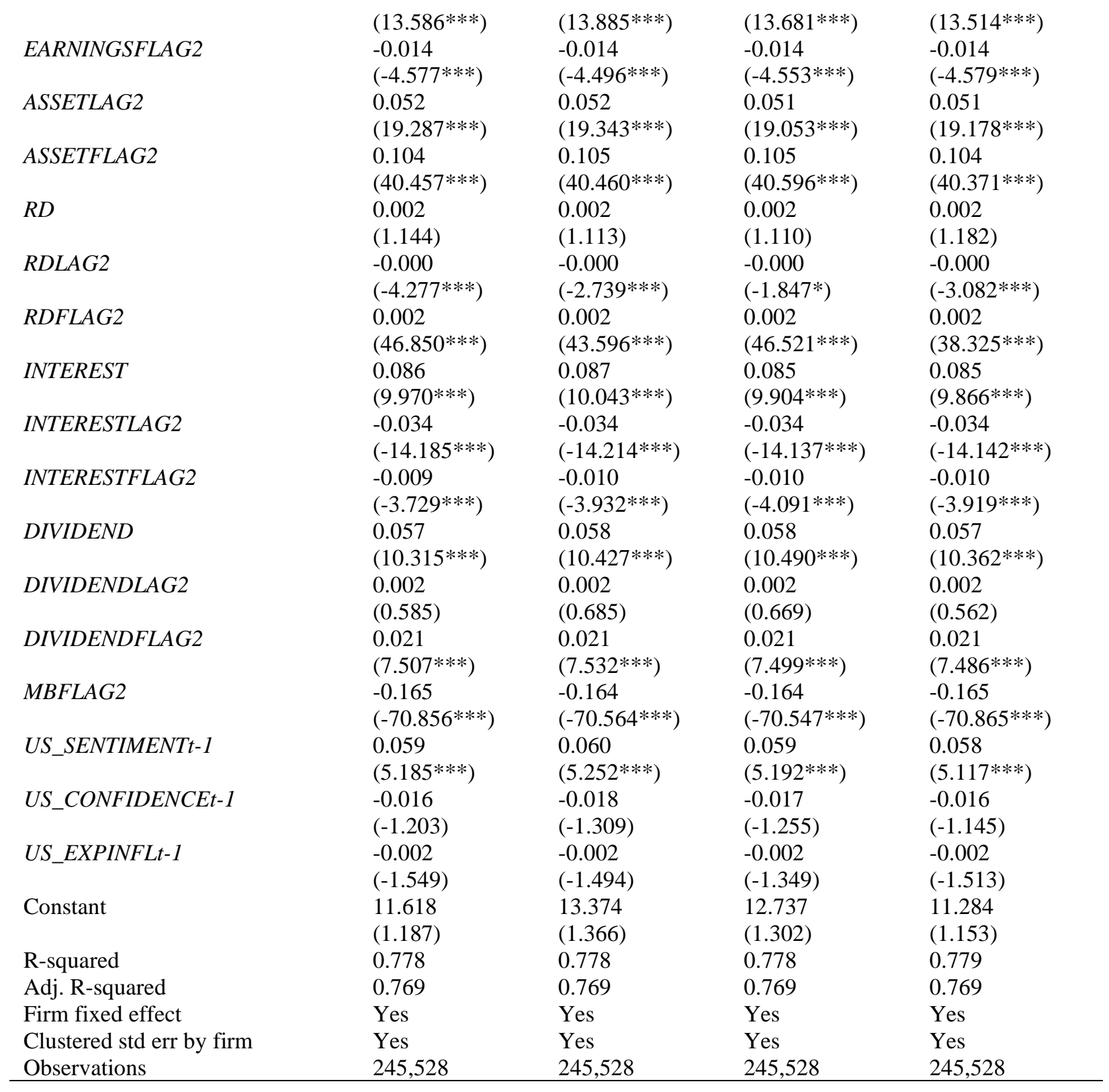




\section{Table 12 - Impact on Firm Value - Subsamples Based upon Industry Concentration - Sales-Based Herfindahl Index}

In this table, we examine the impact of EPU and trade credit policy on firm value for the subsamples of firms in industry with high vs. low concentration. We measure industry concentration by the sales-based Herfindahl index. The dependent variable $M B$ is the market value of assets divided by the book value of assets minus trade receivables at time $\mathrm{t}+1$, where time $\mathrm{t}$ is the year of EPU. RECEIVABLES is the ratio of trade receivables to total assets minus trade receivables. ASSET is total assets minus trade receivables. PAYABLES is the ratio of trade payables to cost of goods sold. REC_DAYS is RECEIVABLES divided by the actual number of days in a year. PAY_DAYS is PAYABLE divided by the actual number of days in a year. EPU_LAST is the natural log of the composite economic policy uncertainty index and news-based economic policy uncertainty index in the last month of each quarter. EARNINGS is the earnings before extraordinary items scaled by assets minus trade receivables at time $\mathrm{t}+1$. EARNINGSLAG2 (EARNINGSFLAG2) is the change in the earnings levels from time $\mathrm{t}-1$ to time $\mathrm{t}+1(\mathrm{t}+1$ to time $\mathrm{t}+3)$ scaled by assets minus trade receivables at time $\mathrm{t}+1$. ASSETLAG2 (ASSETFLAG2) is the change in the asset levels from time $\mathrm{t}-1$ to time $\mathrm{t}+1(\mathrm{t}+1$ to time $\mathrm{t}+3)$ scaled by assets minus trade receivables at time $\mathrm{t}+1 . R D$ is research and development expenses at time $\mathrm{t}+1$ scaled by assets minus trade receivables at time $\mathrm{t}+1$. RDLAG2 (RDFLAG2) is the change in the R\&D levels from time $\mathrm{t}-1$ to time $\mathrm{t}+1(\mathrm{t}+1$ to time $\mathrm{t}+3)$ scaled by assets minus trade receivables at time $\mathrm{t}+1$. INTEREST is total interest expenses at time $\mathrm{t}+1$ scaled by assets minus trade receivables at time $\mathrm{t}+1$. INTERESTLAG2 (INTERESTFLAG2) is the change in the interest levels from time $\mathrm{t}-1$ to time $\mathrm{t}+1(\mathrm{t}+1$ to time $\mathrm{t}+3)$ scaled by assets minus trade receivables at time $\mathrm{t}+1$. DIVIDENDS is total dividends paid at time $\mathrm{t}+1$ scaled by assets minus trade receivables at time $\mathrm{t}+1$. DIVIDENDSLAG2 (DIVIDENDSFLAG2) is the change in the dividend levels from time $\mathrm{t}-1$ to time $\mathrm{t}+1(\mathrm{t}+1$ to time $\mathrm{t}+3)$ scaled by assets minus trade receivables at time $\mathrm{t}+1$. MBFLAG2 is the change in $M B$ from time $\mathrm{t}+1$ to time $\mathrm{t}+3$ scaled by assets minus trade receivables at time $\mathrm{t}+1$. US_SENTIMENT is the natural logarithm of the consumer sentiment index in the US in the last month of each quarter as provided by University of Michigan. US_CONFIDENCE is the natural logarithm of the composite confidence indicator for US in the last month of each quarter as provided by OECD. US_EXPINFL is the expected inflation in the last month of each quarter as provided by University of Michigan. *, ** and *** indicate the significance levels of $10 \%, 5 \%$ and $1 \%$, respectively.

\begin{tabular}{|c|c|c|c|c|c|c|c|c|}
\hline \multirow[b]{2}{*}{ Variables } & \multicolumn{4}{|c|}{ Panel A - Low Concentration } & \multicolumn{4}{|c|}{ Panel B - High Concentration } \\
\hline & Model 1 & Model 2 & Model 3 & Model 4 & Model 1 & Model 2 & Model 3 & Model 4 \\
\hline EPU_LAST & $\begin{array}{l}-0.009 \\
(-0.860)\end{array}$ & $\begin{array}{l}-0.043 \\
\left(-6.034^{* * *}\right)\end{array}$ & $\begin{array}{l}-0.037 \\
\left(-8.065^{* * *}\right)\end{array}$ & $\begin{array}{l}-0.021 \\
(-1.888 *)\end{array}$ & $\begin{array}{l}-0.023 \\
(-2.304 * *)\end{array}$ & $\begin{array}{l}-0.045 \\
(-7.152 * * *)\end{array}$ & $\begin{array}{l}-0.045 \\
(-10.608 * * *)\end{array}$ & $\begin{array}{l}-0.028 \\
\left(-2.561^{* *}\right)\end{array}$ \\
\hline REC_DAYS & $\begin{array}{l}0.349 \\
\left(2.153^{* *}\right)\end{array}$ & & & $\begin{array}{l}0.329 \\
\left(2.017^{* *}\right)\end{array}$ & $\begin{array}{l}0.211 \\
(1.370)\end{array}$ & & & $\begin{array}{l}0.181 \\
(1.171)\end{array}$ \\
\hline$R E C \_D A Y S \times E P U \_L A S T$ & $\begin{array}{l}-0.406 \\
(-2.539 * *)\end{array}$ & & & $\begin{array}{l}-0.383 \\
(-2.380 * *)\end{array}$ & $\begin{array}{l}-0.300 \\
(-1.972 * *)\end{array}$ & & & $\begin{array}{l}-0.270 \\
(-1.767 *)\end{array}$ \\
\hline$R E C \_D A Y S^{2}$ & $\begin{array}{l}-0.332 \\
(-2.109 * *)\end{array}$ & & & $\begin{array}{l}-0.275 \\
\left(-1.736^{*}\right)\end{array}$ & $\begin{array}{l}-0.180 \\
(-1.175)\end{array}$ & & & $\begin{array}{l}-0.124 \\
(-0.795)\end{array}$ \\
\hline$R E C \_D A Y S^{2} \times E P U \_L A S T$ & $\begin{array}{l}0.347 \\
(2.236 * *)\end{array}$ & & & $\begin{array}{l}0.286 \\
(1.830 *)\end{array}$ & $\begin{array}{l}0.220 \\
(1.436)\end{array}$ & & & $\begin{array}{l}0.157 \\
(1.012)\end{array}$ \\
\hline PAY_DAYS & & $\begin{array}{l}-0.225 \\
(-1.172)\end{array}$ & & $\begin{array}{l}-0.301 \\
(-1.545)\end{array}$ & & $\begin{array}{l}0.029 \\
(0.179)\end{array}$ & & $\begin{array}{l}-0.037 \\
(-0.231)\end{array}$ \\
\hline$P A Y \_D A Y S \times E P U \_L A S T$ & & $\begin{array}{l}0.178 \\
(0.934)\end{array}$ & & $\begin{array}{l}0.269 \\
(1.390)\end{array}$ & & $\begin{array}{l}-0.013 \\
(-0.083)\end{array}$ & & $\begin{array}{l}0.079 \\
(0.502)\end{array}$ \\
\hline$P A Y \_D A Y S^{2}$ & & $\begin{array}{l}0.032 \\
(0.172)\end{array}$ & & $\begin{array}{l}0.109 \\
(0.582)\end{array}$ & & $\begin{array}{l}-0.114 \\
(-0.700)\end{array}$ & & $\begin{array}{l}-0.054 \\
(-0.332)\end{array}$ \\
\hline$P A Y \_D A Y S^{2} \times E P U \_L A S T$ & & $\begin{array}{l}0.026 \\
(0.139)\end{array}$ & & $\begin{array}{l}-0.061 \\
(-0.325)\end{array}$ & & $\begin{array}{l}0.115 \\
(0.708)\end{array}$ & & $\begin{array}{l}0.039 \\
(0.244)\end{array}$ \\
\hline$N E T \_D A Y S$ & & & $\begin{array}{l}0.243 \\
\left(2.164^{* *}\right)\end{array}$ & & & & $\begin{array}{l}0.137 \\
(1.379)\end{array}$ & \\
\hline
\end{tabular}




\begin{tabular}{|c|c|c|c|c|c|c|c|c|}
\hline \multicolumn{3}{|l|}{ NET_DAYS $\times$ EPU_LAST } & \multicolumn{4}{|c|}{$\begin{array}{l}-0.275 \\
(-2.397 * *)\end{array}$} & \multicolumn{2}{|c|}{$\begin{array}{l}-0.198 \\
(-2.007 * *)\end{array}$} \\
\hline$N E T \_D A Y S^{2}$ & & & $\begin{array}{l}0.047 \\
(0.427)\end{array}$ & & & & $\begin{array}{l}0.049 \\
(0.462)\end{array}$ & \\
\hline$N E T \_D A Y S^{2} \times E P U \_L A S T$ & & & -0.057 & & & & -0.079 & \\
\hline R-squared & 0.775 & 0.775 & 0.775 & 0.776 & 0.801 & 0.800 & 0.801 & 0.801 \\
\hline Adj. R-squared & 0.763 & 0.763 & 0.763 & 0.763 & 0.790 & 0.790 & 0.790 & 0.790 \\
\hline Control variables & Yes & Yes & Yes & Yes & Yes & Yes & Yes & Yes \\
\hline Firm fixed effect & Yes & Yes & Yes & Yes & Yes & Yes & Yes & Yes \\
\hline Clustered std err by firm & Yes & Yes & Yes & Yes & Yes & Yes & Yes & Yes \\
\hline Observations & 122,162 & 122,162 & 122,162 & 122,162 & 123,366 & 123,366 & 123,366 & 123,366 \\
\hline
\end{tabular}




\section{Internet Appendix}

Table IA.1 - Impact of EPU on Trade Credit Policy - Average Composite EPU in Each Quarter

In this table, we examine the impact of EPU on firm trade credit policy. The dependent variables are REC_DAYS in Model 1, PAY_DAYS in Model 2 and NET_DAYS in Model 3. RECEIVABLES is the ratio of trade receivables to total assets minus trade receivables. ASSET is total assets minus trade receivables. PAYABLES is the ratio of trade payables to cost of goods sold. REC_DAYS is RECEIVABLES divided by the actual number of days in a year. PAY_DAYS is PAYABLE divided by the actual number of days in a year. EPU_MEAN is the natural logarithm of the average monthly EPU value in each quarter. GROSSMARGIN is the ratio of the difference between sales and cost of goods sold scaled by sales. SALE / ASSET is the ratio of sales to total assets minus trade receivables. FREE COLLATERAL is the difference between net property plant and equipment and long-term debt scaled by total assets minus trade receivables. CASH/ASSET is the ratio of cash to total assets minus trade receivables. SHORTDEBT/ASSET is the ratio of short-term debt to total assets minus trade receivables. RSI is the ratio of R\&D expenditures to total assets minus trade receivables. *, ** and $* * *$ indicate the significance levels of $10 \%, 5 \%$ and $1 \%$, respectively.

\begin{tabular}{llll}
\hline Variables & Model 1 - REC_DAYS & Model 2 - PAY_DAYS & Model 3 - NET_DAYS \\
\hline EPU_MEANt-1 & -0.012 & -0.004 & 0.000 \\
& $\left(-4.951^{* * *}\right)$ & $\left(-2.527^{* *}\right)$ & $(0.085)$ \\
GROSSMARGINt-1 & -0.014 & 0.170 & -0.186 \\
& $\left(-2.252^{* *}\right)$ & $\left(19.193^{* * *}\right)$ & $\left(-21.374^{* * *}\right)$ \\
SALE/ASSETt-1 & -0.070 & -0.097 & 0.072 \\
& $\left(-11.754^{* * *}\right)$ & $\left(-13.055^{* * *}\right)$ & $\left(10.391^{* * *}\right)$ \\
FREE COLLATERALt-1 & 0.004 & -0.010 & 0.011 \\
& $(0.850)$ & $\left(-1.816^{*}\right)$ & $\left(1.897^{*}\right)$ \\
CASH/ASSETt-1 & -0.013 & -0.037 & 0.031 \\
& $\left(-1.771^{*}\right)$ & $\left(-4.963^{* * *}\right)$ & $\left(4.098^{* * *}\right)$ \\
SHORTDEBT/ASSETt-1 & -0.015 & 0.101 & -0.100 \\
& $\left(-2.442^{* *}\right)$ & $\left(13.189^{* * *}\right)$ & $\left(-13.570^{* * *}\right)$ \\
RSIt-1 & -0.017 & 0.027 & -0.035 \\
& $\left(-2.226^{* *}\right)$ & $\left(3.305^{* * *}\right)$ & $\left(-4.182^{* * *}\right)$ \\
Constant & 48.249 & 81.300 & -30.123 \\
& $\left(32.633^{* * *}\right)$ & $\left(18.216^{* * *}\right)$ & $\left(-7.084^{* * *}\right)$ \\
R-squared & 0.680 & 0.693 & 0.683 \\
Adj. R-squared & 0.666 & 0.680 & 0.670 \\
Firm fixed effect & Yes & Yes & Yes \\
Year fixed effect & Yes & Yes & Yes \\
Clustered std err by firm & Yes & Yes & Yes \\
Observations & 274,363 & 274,363 & 274,363 \\
\hline
\end{tabular}


Table IA.2 - Impact of EPU on Trade Credit Policy - Last News-Based EPU in a Quarter

In this table, we examine the impact of EPU on firm trade credit policy. The dependent variables are REC_DAYS in Model 1, PAY_DAYS in Model 2 and NET_DAYS in Model 3. RECEIVABLES is the ratio of trade receivables to total assets minus trade receivables. ASSET is total assets minus trade receivables. PAYABLES is the ratio of trade payables to cost of goods sold. REC_DAYS is RECEIVABLES divided by the actual number of days in a year. PAY_DAYS is PAYABLE divided by the actual number of days in a year. NEWS EPU LASTt-1 is the natural logarithm of the news-based EPU value in the last month of each quarter. GROSSMARGIN is the ratio of the difference between sales and cost of goods sold scaled by sales. SALE / ASSET is the ratio of sales to total assets minus trade receivables. FREE COLLATERAL is the difference between net property plant and equipment and long-term debt scaled by total assets minus trade receivables. CASH/ASSET is the ratio of cash to total assets minus trade receivables. SHORTDEBT/ASSET is the ratio of short-term debt to total assets minus trade receivables. $R S I$ is the ratio of $\mathrm{R} \& \mathrm{D}$ expenditures to total assets minus trade receivables. $*$, ** and $* * *$ indicate the significance levels of $10 \%, 5 \%$ and $1 \%$, respectively.

\begin{tabular}{|c|c|c|c|c|c|c|}
\hline \multirow[b]{2}{*}{ Variables } & \multicolumn{2}{|c|}{ Panel A - REC_DAYS } & \multicolumn{2}{|c|}{ Panel B - PAY_DAYS } & \multicolumn{2}{|c|}{ Panel C -NET_DAYS } \\
\hline & Model 1 & Model 2 & Model 1 & Model 2 & Model 1 & Model 2 \\
\hline NEWS_EPU_LASTt-1 & $\begin{array}{l}-0.012 \\
(-3.687 * * *)\end{array}$ & $\begin{array}{l}-0.004 \\
(-2.286 * *)\end{array}$ & $\begin{array}{l}-0.014 \\
\left(-4.191^{* * *}\right)\end{array}$ & $\begin{array}{l}-0.013 \\
\left(-8.104^{* * *}\right)\end{array}$ & $\begin{array}{l}0.011 \\
\left(3.345^{* * *}\right)\end{array}$ & $\begin{array}{l}0.012 \\
\left(7.401^{* * *}\right)\end{array}$ \\
\hline GROSSMARGINt-1 & $\begin{array}{l}0.034 \\
\left(4.357^{* * *}\right)\end{array}$ & $\begin{array}{l}-0.015 \\
(-2.342 * *)\end{array}$ & $\begin{array}{l}0.152 \\
(18.259 * * *)\end{array}$ & $\begin{array}{l}0.170 \\
\left(19.190^{* * *}\right)\end{array}$ & $\begin{array}{l}-0.156 \\
\left(-19.610^{* * *}\right)\end{array}$ & $\begin{array}{l}-0.186 \\
\left(-21.381^{* * *}\right)\end{array}$ \\
\hline SALE/ASSETt-1 & $\begin{array}{l}-0.108 \\
(-12.670 * * *)\end{array}$ & $\begin{array}{l}-0.069 \\
(-11.537 * * *)\end{array}$ & $\begin{array}{l}-0.230 \\
(-30.493 * * *)\end{array}$ & $\begin{array}{l}-0.097 \\
\left(-13.036^{* * *}\right)\end{array}$ & $\begin{array}{l}0.195 \\
\left(26.503^{* * *}\right)\end{array}$ & $\begin{array}{l}0.073 \\
(10.410 * * *)\end{array}$ \\
\hline FREE COLLATERALt-1 & $\begin{array}{l}-0.008 \\
(-1.543)\end{array}$ & $\begin{array}{l}0.004 \\
(0.893)\end{array}$ & $\begin{array}{l}-0.019 \\
(-2.042 * *)\end{array}$ & $\begin{array}{l}-0.010 \\
(-1.809 *)\end{array}$ & $\begin{array}{l}0.015 \\
(1.591)\end{array}$ & $\begin{array}{l}0.011 \\
(1.901 *)\end{array}$ \\
\hline CASH/ASSETt-1 & $\begin{array}{l}0.080 \\
\left(8.901^{* * *}\right)\end{array}$ & $\begin{array}{l}-0.011 \\
(-1.476)\end{array}$ & $\begin{array}{l}-0.009 \\
(-1.085)\end{array}$ & $\begin{array}{l}-0.037 \\
\left(-4.973^{* * *}\right)\end{array}$ & $\begin{array}{l}0.038 \\
\left(4.422^{* * *}\right)\end{array}$ & $\begin{array}{l}0.032 \\
\left(4.213^{* * *}\right)\end{array}$ \\
\hline SHORTDEBT/ASSETt-1 & $\begin{array}{l}0.017 \\
\left(2.557^{* *}\right)\end{array}$ & $\begin{array}{l}-0.015 \\
(-2.532 * *)\end{array}$ & $\begin{array}{l}0.319 \\
\left(38.280^{* * *}\right)\end{array}$ & $\begin{array}{l}0.101 \\
(13.191 * * *)\end{array}$ & $\begin{array}{l}-0.302 \\
\left(-37.421^{* * *}\right)\end{array}$ & $\begin{array}{l}-0.100 \\
(-13.589 * * *)\end{array}$ \\
\hline RSIt-1 & $\begin{array}{l}-0.041 \\
\left(-4.695^{* * *}\right)\end{array}$ & $\begin{array}{l}-0.017 \\
\left(-2.227^{* *}\right)\end{array}$ & $\begin{array}{l}0.071 \\
\left(6.475^{* * *}\right)\end{array}$ & $\begin{array}{l}0.027 \\
\left(3.290^{* * *}\right)\end{array}$ & $\begin{array}{l}-0.097 \\
(-9.211 * * *)\end{array}$ & $\begin{array}{l}-0.034 \\
\left(-4.164^{* * *}\right)\end{array}$ \\
\hline Constant & $\begin{array}{l}57.696 \\
(40.863 * * *)\end{array}$ & $\begin{array}{l}56.827 \\
\left(73.378^{* * *}\right)\end{array}$ & $\begin{array}{l}101.784 \\
\left(23.765^{* * *}\right)\end{array}$ & $\begin{array}{l}99.334 \\
(41.849 * * *)\end{array}$ & $\begin{array}{l}-42.171 \\
\left(-10.618^{* * *}\right)\end{array}$ & $\begin{array}{l}-39.361 \\
(-17.287 * * *)\end{array}$ \\
\hline R-squared & 0.017 & 0.680 & 0.131 & 0.693 & 0.116 & 0.683 \\
\hline Adj. R-squared & 0.0169 & 0.666 & 0.131 & 0.680 & 0.116 & 0.670 \\
\hline Firm fixed effect & No & Yes & No & Yes & No & Yes \\
\hline Year fixed effect & No & Yes & No & Yes & No & Yes \\
\hline Clustered std err by firm & Yes & Yes & Yes & Yes & Yes & Yes \\
\hline Observations & 273,397 & 274,363 & 273,397 & 274,363 & 273,397 & 274,363 \\
\hline
\end{tabular}


Table IA.3 - Impact of EPU on Net Trade Credit Days - Firms Reliance on Government Spending

In this table, we examine the impact of EPU on firm trade credit policy separately for the subsample of firms with significance reliance on government spending and the subsample of firms without such reliance. We break down the whole sample into firms with government agency customers vs. firms without government agency customers. The dependent variables are REC_DAYS in Panel A, PAY_DAYS in Panel B and NET_DAYS in Panel C. RECEIVABLES is the ratio of trade receivables to total assets minus trade receivables. ASSET is total assets minus trade receivables. PAYABLES is the ratio of trade payables to cost of goods sold. REC_DAYS is RECEIVABLES divided by the actual number of days in a year. PAY_DAYS is PAYABLE divided by the actual number of days in a year. EPU_LAST is the natural logarithm of the last month's EPU value in each quarter. GROSSMARGIN is the ratio of the difference between sales and cost of goods sold scaled by sales. SALE / ASSET is the ratio of sales to total assets minus trade receivables. FREE COLLATERAL is the difference between net property plant and equipment and long-term debt scaled by total assets minus trade receivables. CASH/ASSET is the ratio of cash to total assets minus trade receivables. SHORTDEBT/ASSET is the ratio of short-term debt to total assets minus trade receivables. RSI is the ratio of R\&D expenditures to total assets minus trade receivables. *, ** and *** indicate the significance levels of $10 \%, 5 \%$ and $1 \%$, respectively.

\begin{tabular}{|c|c|c|c|c|c|c|}
\hline & Panel A - REC_DAYS & & Panel B - PAY_DAYS & & Panel C - REC_DAYS & \\
\hline Variables & $\begin{array}{l}\text { Model 1-Firms with } \\
\text { Government } \\
\text { Customers }\end{array}$ & $\begin{array}{l}\text { Model 2-Firms } \\
\text { without Government } \\
\text { Customers }\end{array}$ & $\begin{array}{l}\text { Model 1-Firms with } \\
\text { Government } \\
\text { Customers }\end{array}$ & $\begin{array}{l}\text { Model 2-Firms } \\
\text { without Government } \\
\text { Customers }\end{array}$ & $\begin{array}{l}\text { Model 1-Firms with } \\
\text { Government } \\
\text { Customers }\end{array}$ & $\begin{array}{l}\text { Model 2-Firms } \\
\text { without Government } \\
\text { Customers }\end{array}$ \\
\hline EPU_LASTt-1 & $\begin{array}{l}-0.018 \\
(-2.192 * *)\end{array}$ & $\begin{array}{l}-0.005 \\
\left(-2.250^{* *}\right)\end{array}$ & $\begin{array}{l}-0.023 \\
(-2.782 * * *)\end{array}$ & $\begin{array}{l}-0.016 \\
\left(-7.238^{* * *}\right)\end{array}$ & $\begin{array}{l}0.017 \\
\left(1.804^{*}\right)\end{array}$ & $\begin{array}{l}0.015 \\
\left(6.712^{* * *}\right)\end{array}$ \\
\hline GROSSMARGINt-1 & $\begin{array}{l}0.018 \\
(0.760)\end{array}$ & $\begin{array}{l}-0.016 \\
\left(-2.458^{* *}\right)\end{array}$ & $\begin{array}{l}0.113 \\
\left(1.861^{*}\right)\end{array}$ & $\begin{array}{l}0.172 \\
(19.064 * * *)\end{array}$ & $\begin{array}{l}-0.116 \\
\left(-1.872^{*}\right)\end{array}$ & $\begin{array}{l}-0.188 \\
(-21.382 * * *)\end{array}$ \\
\hline SALE/ASSETt-1 & $\begin{array}{l}-0.075 \\
(-2.578 * *)\end{array}$ & $\begin{array}{l}-0.068 \\
(-11.382 * * *)\end{array}$ & $\begin{array}{l}-0.077 \\
(-2.522 * *)\end{array}$ & $\begin{array}{l}-0.099 \\
(-12.786 * * *)\end{array}$ & $\begin{array}{l}0.025 \\
(0.789)\end{array}$ & $\begin{array}{l}0.075 \\
(10.490 * * *)\end{array}$ \\
\hline FREE COLLATERALt-1 & $\begin{array}{l}0.001 \\
(0.043)\end{array}$ & $\begin{array}{l}0.004 \\
(0.929)\end{array}$ & $\begin{array}{l}-0.014 \\
(-0.414)\end{array}$ & $\begin{array}{l}-0.011 \\
(-1.848 *)\end{array}$ & $\begin{array}{l}0.011 \\
(0.315)\end{array}$ & $\begin{array}{l}0.011 \\
\left(1.958^{*}\right)\end{array}$ \\
\hline CASH/ASSETt-1 & $\begin{array}{l}-0.018 \\
(-0.673)\end{array}$ & $\begin{array}{l}-0.010 \\
(-1.381)\end{array}$ & $\begin{array}{l}-0.065 \\
(-2.289 * *)\end{array}$ & $\begin{array}{l}-0.037 \\
(-4.750 * * *)\end{array}$ & $\begin{array}{l}0.045 \\
(1.536)\end{array}$ & $\begin{array}{l}0.032 \\
\left(4.111^{* * *}\right)\end{array}$ \\
\hline SHORTDEBT/ASSETt-1 & $\begin{array}{l}-0.021 \\
(-1.451)\end{array}$ & $\begin{array}{l}-0.015 \\
\left(-2.417^{* *}\right)\end{array}$ & $\begin{array}{l}0.033 \\
(1.028)\end{array}$ & $\begin{array}{l}0.102 \\
(13.018 * * *)\end{array}$ & $\begin{array}{l}-0.035 \\
(-1.192)\end{array}$ & $\begin{array}{l}-0.102 \\
(-13.401 * * *)\end{array}$ \\
\hline RSIt-1 & $\begin{array}{l}-0.009 \\
(-0.299)\end{array}$ & $\begin{array}{l}-0.018 \\
(-2.241 * *)\end{array}$ & $\begin{array}{l}0.053 \\
(1.672 *)\end{array}$ & $\begin{array}{l}0.027 \\
\left(3.121^{* * *}\right)\end{array}$ & $\begin{array}{l}-0.059 \\
(-1.535)\end{array}$ & $\begin{array}{l}-0.034 \\
(-3.992 * * *)\end{array}$ \\
\hline Constant & $\begin{array}{l}70.634 \\
\left(20.063^{* * *}\right)\end{array}$ & $\begin{array}{l}57.098 \\
\left(50.997^{* * *}\right)\end{array}$ & $\begin{array}{l}68.110 \\
\left(8.035^{* * *}\right)\end{array}$ & $\begin{array}{l}108.816 \\
\left(31.817^{* * *}\right)\end{array}$ & $\begin{array}{l}4.664 \\
(0.516)\end{array}$ & $\begin{array}{l}-48.852 \\
\left(-14.885^{* * *}\right)\end{array}$ \\
\hline R-squared & 0.679 & 0.681 & 0.682 & 0.693 & 0.671 & 0.682 \\
\hline Adj. R-squared & 0.663 & 0.668 & 0.666 & 0.679 & 0.655 & 0.668 \\
\hline Firm fixed effect & Yes & Yes & Yes & Yes & Yes & Yes \\
\hline Year fixed effect & Yes & Yes & Yes & Yes & Yes & Yes \\
\hline Clustered std err by firm & Yes & Yes & Yes & Yes & Yes & Yes \\
\hline Observations & 17,704 & 256,659 & 17,704 & 256,659 & 17,704 & 256,659 \\
\hline
\end{tabular}


Table IA.4- Correlation Matrix

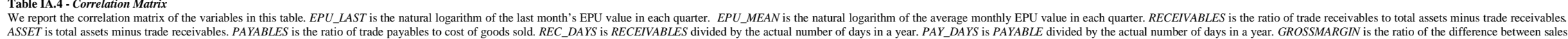
and cost of goods sold scaled by sales. SALE / ASSET is the ratio of sales to total assets minus trade receivables. FREE COLLATERAL is the difference between net property plant and equipment and long-term debt scaled by total assets minus trade receivables. CASH/ASSET is the ratio of cash to total assets minus trade receivables. SHORTDEBT/ASSET is the ratio of short-term debt to total assets minus trade receivables. $R S I$ is the ratio of R\&D expenditures to total assets minus trade receivables. WW index is the Whited-Wu financial constraint index (Whited and Wu 2006 ) , calculated as $(-0.091 *$ operating cash flow to asset ratio -
$0.062 *$ dummy for firms paying dividend in the year $+0.021 *$ long-term debt to total assets $-0.044 * \ln ($ firm assets) $+0.1021 *$ annual SIC 3 -digit industry growth $-0.035 *$ firm annual growth). DIFFGOODS and $S T D G O O D S$ are the dummy variables for firms producing differentiated goods and fims producing

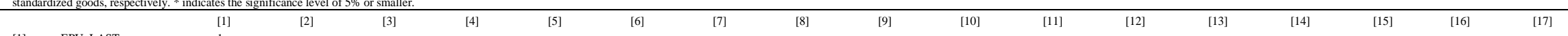

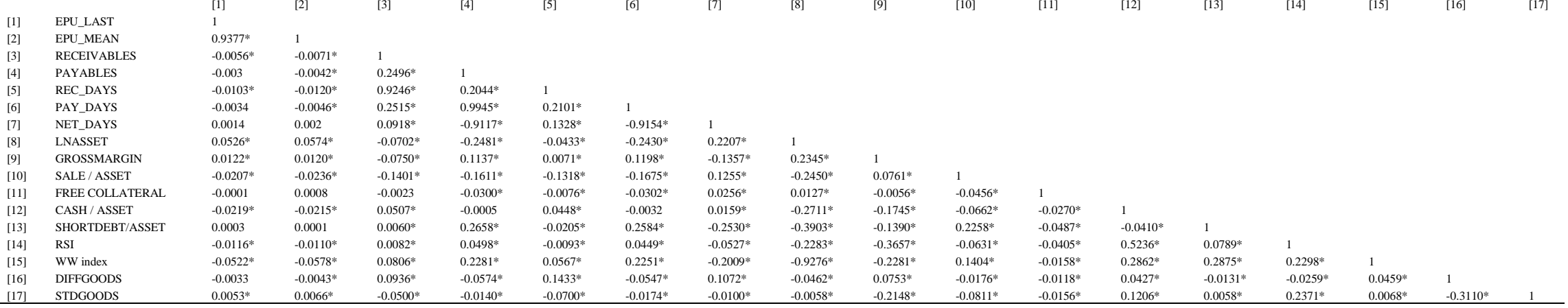

